\title{
An updated tribal classification of Lamiaceae based on plastome phylogenomics
}

Fei Zhao ${ }^{1 \dagger}$, Ya-Ping Chen ${ }^{1 \dagger}$, Yasaman Salmaki ${ }^{2}$, Bryan T. Drew ${ }^{3}$, Trevor C. Wilson ${ }^{4}$, Anne-Cathrine Scheen ${ }^{5}$, Ferhat Celep ${ }^{6,7}$, Christian Bräuchler ${ }^{8}$, Mika Bendiksby ${ }^{9,10}$, Qiang Wang ${ }^{11}$, Dao-Zhang Min ${ }^{12}$, Hua Peng ${ }^{1}$, Richard G. Olmstead ${ }^{13}$, Bo Li ${ }^{12^{*}}$ and Chun-Lei Xiang ${ }^{1 *}$

\begin{abstract}
Background: A robust molecular phylogeny is fundamental for developing a stable classification and providing a solid framework to understand patterns of diversification, historical biogeography, and character evolution. As the sixth largest angiosperm family, Lamiaceae, or the mint family, consitutes a major source of aromatic oil, wood, ornamentals, and culinary and medicinal herbs, making it an exceptionally important group ecologically, ethnobotanically, and floristically. The lack of a reliable phylogenetic framework for this family has thus far hindered broad-scale biogeographic studies and our comprehension of diversification. Although significant progress has been made towards clarifying Lamiaceae relationships during the past three decades, the resolution of a phylogenetic backbone at the tribal level has remained one of the greatest challenges due to limited availability of genetic data.

Results: We performed phylogenetic analyses of Lamiaceae to infer relationships at the tribal level using 79 protein-coding plastid genes from 175 accessions representing 170 taxa, 79 genera, and all 12 subfamilies. Both maximum likelihood and Bayesian analyses yielded a more robust phylogenetic hypothesis relative to previous studies and supported the monophyly of all 12 subfamilies, and a classification for 22 tribes, three of which are newly recognized in this study. As a consequence, we propose an updated phylogenetically informed tribal classification for Lamiaceae that is supplemented with a detailed summary of taxonomic history, generic and species diversity, morphology, synapomorphies, and distribution for each subfamily and tribe.
\end{abstract}

Conclusions: Increased taxon sampling conjoined with phylogenetic analyses based on plastome sequences has provided robust support at both deep and shallow nodes and offers new insights into the phylogenetic relationships among tribes and subfamilies of Lamiaceae. This robust phylogenetic backbone of Lamiaceae will serve as a framework for future studies on mint classification, biogeography, character evolution, and diversification.

Keywords: Lamiaceae, Lamioideae, Mints, Phylogenomics, Tribal relationships

\footnotetext{
* Correspondence: hanbolijx@163.com; xiangchunlei@mail.kib.ac.cn

${ }^{\dagger}$ Fei Zhao and Ya-Ping Chen contributed equally to this work.

${ }^{12}$ Research Centre of Ecological Sciences, College of Agronomy, Jiangxi

Agricultural University, Nanchang 330045, China

'CAS Key Laboratory for Plant Diversity and Biogeography of East Asia,

Kunming Institute of Botany, Chinese Academy of Sciences, Kunming 650201, China

Full list of author information is available at the end of the article
}

(C) The Author(s). 2021 Open Access This article is licensed under a Creative Commons Attribution 4.0 International License, which permits use, sharing, adaptation, distribution and reproduction in any medium or format, as long as you give appropriate credit to the original author(s) and the source, provide a link to the Creative Commons licence, and indicate if changes were made. The images or other third party material in this article are included in the article's Creative Commons licence, unless indicated otherwise in a credit line to the material. If material is not included in the article's Creative Commons licence and your intended use is not permitted by statutory regulation or exceeds the permitted use, you will need to obtain permission directly from the copyright holder. To view a copy of this licence, visit http://creativecommons.org/licenses/by/4.0/. The Creative Commons Public Domain Dedication waiver (http://creativecommons.org/publicdomain/zero/1.0/) applies to the data made available in this article, unless otherwise stated in a credit line to the data. 


\section{Background}

Lamiaceae, generally known as the mint family, have long been known for their aromatic oils, which have played an undeniably significant role within culinary, medicinal, and horticultural aspects of human history. Species of Lamiaceae are of wide economic importance as sources of wood (e.g., Tectona grandis L. f.), landscape ornamentals (e.g., scarlet sage [Salvia splendens Sellow ex Wied-Neuw.]), cosmetics (e.g., lavender [Lavandula angustifolia Mill.]), culinary herbs (e.g., basil [Ocimum basilicum L.], oregano [Origanum vulgare L.], thyme [Thymus vulgaris L.]), and medicinal herbs (e.g., Korean mint [Agastache rugosa (Fisch. \& C.A. Mey.) Kuntze], peppermint [Mentha $\times$ piperita L.]). Despite the recognition of this family (Lamiaceae s.s.) from advances in systematics and taxonomy of the late twentieth century, the family has historically been considered a "natural" group based on a combination of readily recognizable features such as an herbaceous habit, quadrangular stems, opposite phyllotaxy, bilabiate flowers, a gynobasic style, and four nutlets. However, morphological and molecular phylogenetic studies in the past three decades have significantly changed the concept of the family, and an expanded Lamiaceae (Lamiaceae s.l.) is now widely accepted. As currently circumscribed, Lamiaceae comprise more than 230 genera and over 7000 species, making it the sixth largest angiosperm family and the largest family in the order Lamiales [1-3]. Although unequivocally shown to be members of the family, inclusion of some disparate groups such as Vitex L. (originally placed in Verbenaceae because they were trees with fleshy fruits) has challenged the earlier concepts of the family.

Early infrafamilial classifications within Lamiaceae were predominately based on the treatment of Bentham [4], who divided the family into eight tribes. Briquet [5], for example, followed the division of Bentham [4], but raised some of the tribes to subfamilial rank and merged four tribes into the single large subfamily Lamioideae. Erdtman [6], however, recognized only two subfamilies based on palynological distinctions, viz., Lamioideae (with tricolpate pollen shed at the two-celled stage) and Nepetoideae (with hexacolpate pollen shed at the threecelled stage). Combining the classifications of Briquet [5] and Erdtman [6], Wunderlich [7] recognized six subfamilies within Lamiaceae, rejecting Lamioideae as circumscribed by Briquet [5] and accepting a subfamily Nepetoideae close to that of Erdtman [6]. Cantino and Sanders [8] revealed that Nepetoideae sensu Erdtman [6] is monophyletic with several synapomorphies, whereas no synapomorphy was found for Lamioideae sensu Erdtman [6].

The mint family has long been thought to have evolved from Verbenaceae-like ancestors, and these two families were considered separate largely based upon gynoecial structure. Although a deeply four-lobed ovary with a gynobasic style is typical for most traditionally recognized Lamiaceae (i.e. Lamiaceae s.s.), and an unlobed ovary with a terminal style is typical of most Verbenaceae, there exists in both families a continuum in extent of lobing and separation of fruits into single seeded units [9]. Noting this, Cantino [9, 10] carried out a cladistic analysis of the Lamiaceae s.s. and the Verbenaceae s.l. based on 85 morphological and anatomical characters, which provided support to reject that the Lamiaceae s.s. was monophyletic, demonstrating several clades of the Verbenaceae s.l. recovered among clades of the Lamiaceae s.s. Based on these results, Cantino et al. [11] published a list of subfamilies and genera of the Lamiaceae s.l. that had been proposed earlier by Junell [12]. This incorporated the transfer of the cymose subfamilies Caryopteridoideae, Chloanthoideae, Viticoideae, Symphorematoideae, and tribe Monochileae to the expanded Lamiaceae, rendering the Verbenaceae s.s. as only the subfamily Verbenoideae. Verbenaceae s.s. can be recognized by having racemose inflorescences, tricolporate pollen, and ovules attached to the carpel margins, while the Lamiaceae s.l. generally possess thyrsoid inflorescences, colpate pollen, and ovules attached to the sides of the false septa of ovary [13]. Moreover, the Verbenaceae s.s. have thickened stigma lobes with conspicuous stigmatic tissue, hypocrateriform corollas with included stamens, and usually terete stems, whereas in the Lamiaceae s.l., stigma lobes are slender with inconspicuous stigmatic tissue, corollas that are rarely hypocrateriform, and stems are typically quadrangular. Since Cantino et al. [11], the expanded concept of the Lamiaceae s.l. has been consistently supported as monophyletic by molecular phylogenetic studies [14-20] and is widely accepted in various classifications [1, 3]. We acknowledge these results and use the names Lamiaceae and Verbenaceae in their contemporary circumscription. Though today both Lamiaceae and Verbenaceae are placed within "core Lamiales" of the asterids, they have unexpectedly not been recovered as sister taxa despite their morphological similarities: Lamiaceae belong to a clade that includes Mazaceae, Phrymaceae, Wightiaceae, Paulowniaceae, and Orobanchaceae, whereas Verbenaceae are recovered as sister to Thomandersiaceae [18, 21, 22].

Following Cantino et al. [11], Harley et al. [1] published a global, genus-level taxonomic conspectus of Lamiaceae. Except for the ten genera Acrymia Prain, Callicarpa L., Cymaria Benth., Garrettia H.R. Fletch., Holocheila (Kudô) S. Chow, Hymenopyramis Wall. ex Griff., Ombrocharis Hand.-Mazz., Peronema Jack, Petraeovitex Oliv., and Tectona L. that were treated as incertae sedis, the remaining 226 genera were assigned to seven subfamilies: Ajugoideae, Lamioideae, Nepetoideae, Prostantheroideae, Scutellarioideae, Symphorematoideae, and Viticoideae [1]. Since 
the publication of this classification [1], numerous molecular phylogenetic studies have been carried out to explore the relationships at the subfamilial [19], tribal [23-33], or generic [34-50] level. However, relationships among four subfamilies (Nepetoideae, Tectonoideae, Premnoideae, and Ajugoideae) remain unresolved and those among some tribes were also unclear in those studies.

In terms of taxon number, the most comprehensively sampled phylogenetic study of Lamiaceae was conducted by $\mathrm{Li}$ et al. [19] using an ingroup sampling of 288 species from 191 genera and employing five plastid DNA regions (matK, $n d h F, r b c L$, rps16, and $\operatorname{trnL}-\operatorname{trn} F$ ). The backbone of this phylogeny was comprised of 12 clades, all provided with high branch support, and seven of which corresponded to a portion of the Viticoideae and six of the previously recognized subfamilies of Harley et al. [1]. The other five clades consisted of previously incertae sedis genera and were each provided subfamilial rank as the Cymarioideae (including Acrymia and Cymaria), Peronematoideae (including Hymenopyramis, Petraeovitex, Peronema, and Garrettia), Premnoideae (including Premna L., Gmelina L., and Cornutia L.), Callicarpoideae (including Callicarpa), and Tectonoideae (including Tectona) [19, 51].

Despite the improved resolution in our understanding of Lamiaceae and its subfamilies, the work by $\mathrm{Li}$ et al. [19] was not able to clarify relationships among Nepetoideae, Tectonoideae, Premnoideae, and Ajugoideae, nor were they able to provide resolution to understand the tribal classification within some subfamilies (viz. Lamioideae). While recent phylogenetic analyses have greatly improved our understanding of the major lineages and classifications of Lamioideae [52, 53], the tribal membership of Betonica L., Colquhounia Wall., Galeopsis L., Metastachydium Airy Shaw ex C.Y. Wu \& H.W. Li, Paralamium Dunn., and Roylea Wall. ex Benth. remains unclear [2, 53]. Furthermore, Xiang et al. [54] identified four major clades within the Ajugoideae, but did not propose a formal tribal classification. The uncertain relationships among and within these subfamilies have hindered the further study of character evolution and diversification patterns within Lamiaceae.

Next-generation sequencing (NGS) provides a significantly larger amount of DNA sequence data than has been previously available for phylogenetic studies within angiosperms [55]. While the use of complete plastome sequences is not a panacea [56], it has successfully resolved previously intractable phylogenetic problems within flowering plants at multiple taxonomic levels [57-65]. Concordantly, recent phylogenomic studies based on plastome sequences have provided new insight into both generic and species-level relationships within Scutellarioideae [66] and Salvia [67], respectively. In order to resolve the remaining ambiguities at the tribal and subfamilial level, we sequenced and analyzed the complete plastome for 175 representative taxa from all currently recognized tribes in the 12 subfamilies of Lamiaceae. The focus of this study was to (1) improve the resolution of the phylogenetic backbone of Lamiaceae, (2) modify the tribal classification of Lamiaceae based on our results, and (3) provide a summary of the recent phylogenetic and taxonomic progress achieved for each subfamily and tribe.

\section{Results}

Characteristic of plastome features and datasets

Our sequencing generated between 13,829,468 (Siphocranion flavidum Y.P. Chen \& C.L. Xiang) and 81,265, 290 (Chloanthes coccinea Bartl.) clean reads from the 50 newly sequenced species, with the mean base coverage ranging from $110 \times$ (Congea tomentosa Roxb.) to 3104× (Lamium amplexicaule L.) estimated by the GetOrganelle pipeline [68]. Since we failed to assemble the complete plastome of Callicarpa americana L., the average base coverage for this species is unavailable (noted as "NA" in Table 1). Statistics about the assemblies for each newly sequenced species are provided in Table 1.

All plastomes exhibit a typical quadripartite structure of the large single-copy (LSC, 81,341-85,891 bp) and small single-copy (SSC, 9969-20,681 bp) regions, separated by a pair of inverted repeats (IR regions, 23,085$31,573 \mathrm{bp}$ ). The chloroplast genome maps are provided in Additional file 1 (Fig. S1). The GC content was evenly distributed, and the average GC content was $38.10 \%$ (Additional file 2: Table S1). All the newly sequenced and annotated plastomes in the present study were submitted to the National Center for Biotechnology Information (NCBI) database with accession numbers MT473738-MT473786 (Table 1).

The aligned length of the combined 79 protein-coding regions (CR) is $72,082 \mathrm{bp}$. Removal of ambiguous sites and single-taxon insertions results in an aligned length of 69,822 bp (CRM), of which 41,459 sites are constant (59.38\%). The aligned regions and the excluded ambiguous sites of the individual loci are listed in Additional file 3 (Table S2), and properties of the five datasets are summarized in Table 2.

\section{Phylogenomic analyses}

All analyses yielded an identical topology for the ingroup at the tribal level (Fig. 1; Additional files 4, 5, 6, 7: Figs. S2, S3, S4, S5), although the support is variable among different datasets. All 12 subfamilies were recovered and well-supported in all analyses (Fig. 1; Additional files 4, 5, 6, 7: Figs. S2, S3, S4, S5). The topology recovered by the combined dataset with the ambiguously aligned positions excluded (CRM) is presented as the primary tree 
Table 1 Newly sampled species in this study (NA data unavailable)

\begin{tabular}{|c|c|c|c|c|c|c|}
\hline \multicolumn{2}{|c|}{ Systematic assignment } & \multirow{2}{*}{$\begin{array}{l}\text { Species } \\
\text { Mimulus sp. }\end{array}$} & \multirow{2}{*}{$\begin{array}{l}\text { Locality } \\
\text { The United States Botanic } \\
\text { Garden (USBG), United } \\
\text { States }\end{array}$} & \multirow{2}{*}{$\begin{array}{l}\text { Clean reads } \\
19,584,540\end{array}$} & \multirow{2}{*}{$\begin{array}{l}\begin{array}{l}\text { Mean } \\
\text { coverage } \\
\text { of base }(x)\end{array} \\
478\end{array}$} & \multirow{2}{*}{$\begin{array}{c}\begin{array}{c}\text { GenBank } \\
\text { accession } \\
\text { numbers }\end{array} \\
\text { MT473772 }\end{array}$} \\
\hline $\begin{array}{l}\text { Phrymaceae } \\
\text { (outgroup) }\end{array}$ & & & & & & \\
\hline Ajugoideae & Ajugeae & Caryopteris forrestii Diels & Lijiang, Yunnan, China & $67,295,160$ & 485 & MT473742 \\
\hline Ajugoideae & Teucrieae & $\begin{array}{l}\text { Schnabelia oligophylla } \\
\text { Hand.-Mazz. }\end{array}$ & Kunming, Yunnan, China & $67,359,376$ & 726 & MT473777 \\
\hline Ajugoideae & Clerodendreae & $\begin{array}{l}\text { Clerodendrum japonicum } \\
\text { (Thunb.) Sweet }\end{array}$ & Kunming, Yunnan, China & $69,357,954$ & 854 & MT473745 \\
\hline Ajugoideae & Clerodendreae & $\begin{array}{l}\text { Clerodendrum trichotomum } \\
\text { Thunb. }\end{array}$ & Huairou, Beijing, China & $69,621,568$ & 536 & MT473746 \\
\hline Ajugoideae & Rotheceae & $\begin{array}{l}\text { Rotheca serrata (L.) Steane } \\
\text { \& Mabb. }\end{array}$ & Kunming, Yunnan, China & $69,698,896$ & 328 & MT473776 \\
\hline Callicarpioideae & - & Callicarpa americana L. & $\begin{array}{l}\text { Gainesville, Florida, United } \\
\text { States }\end{array}$ & $69,222,992$ & NA & -- \\
\hline Callicarpioideae & - & Callicarpa arborea Roxb. & Kunming, Yunnan, China & $70,066,596$ & 341 & MT473738 \\
\hline Callicarpioideae & - & $\begin{array}{l}\text { Callicarpa brevipes (Benth.) } \\
\text { Hance }\end{array}$ & $\begin{array}{l}\text { Guangzhou, Guangdong, } \\
\text { China }\end{array}$ & $68,119,222$ & 383 & MT473739 \\
\hline Callicarpioideae & - & Callicarpa macrophylla Vahl & Kunming, Yunnan, China & $69,104,110$ & 499 & MT473740 \\
\hline Callicarpioideae & - & $\begin{array}{l}\text { Callicarpa peichieniana Chun } \\
\& \text { S.L. Chen ex H. Ma } \\
\text { \& W.B. Yu }\end{array}$ & $\begin{array}{l}\text { Guangzhou, Guangdong, } \\
\text { China }\end{array}$ & $68,759,068$ & 215 & MT473741 \\
\hline Cymarioideae & - & Cymaria dichotoma Benth. & Changjiang, Hainan, China & $68,070,464$ & 1189 & MT473753 \\
\hline Lamioideae & Paraphlomideae & $\begin{array}{l}\text { Paraphlomis javanica } \\
\text { (Blume) Prain }\end{array}$ & Kunming, Yunnan, China & $66,797,022$ & 239 & MT473773 \\
\hline Lamioideae & Gomphostemmateae & $\begin{array}{l}\text { Gomphostemma lucidum } \\
\text { Wall. ex Benth. }\end{array}$ & Changjiang, Hainan, China & $66,781,246$ & 274 & MT473764 \\
\hline Lamioideae & Gomphostemmateae & $\begin{array}{l}\text { Chelonopsis souliei (Bonati) } \\
\text { Merr. }\end{array}$ & Litang, Sichuan, China & $67,646,436$ & 572 & MT473743 \\
\hline Lamioideae & Colquhounieae & Colquhounia coccinea Wall. & Kunming, Yunnan, China & $66,842,836$ & 171 & MT473749 \\
\hline Lamioideae & Colquhounieae & Colquhounia seguinii Vaniot & Kunming, Yunnan, China & $66,760,344$ & 337 & MT473750 \\
\hline Lamioideae & Colquhounieae & Colquhounia vestita Wall. & Cuona, Xizang, China & $67,753,130$ & 192 & MT473751 \\
\hline Lamioideae & Lamieae & Lamium amplexicaule L. & Zuogong, Xizang, China & $67,339,814$ & 3104 & MT473770 \\
\hline Lamioideae & Synandreae & Macbridea alba Chapm. & $\begin{array}{l}\text { The United States Botanic } \\
\text { Garden (USBG), } \\
\text { United States }\end{array}$ & $20,514,794$ & 474 & MT473771 \\
\hline Lamioideae & Stachydeae & Galeopsis bifida Boenn. & Deqin, Yunnan, China & $67,442,714$ & 500 & MT473759 \\
\hline Nepetoideae & Elsholtzieae & Elsholtzia densa Benth. & Shangri-La, Yunnan, China & $18,273,016$ & 888 & MT473757 \\
\hline Nepetoideae & Elsholtzieae & Elsholtzia rugulosa Hemsl. & Kunming, Yunnan, China & $67,318,028$ & 553 & MT473758 \\
\hline Nepetoideae & Ocimeae & $\begin{array}{l}\text { Siphocranion flavidum } \\
\text { Y.P. Chen \& C.L. Xiang }\end{array}$ & Malipo, Yunnan, China & $13,829,468$ & 436 & MT473778 \\
\hline Nepetoideae & Ocimeae & $\begin{array}{l}\text { Siphocranion macranthum } \\
\text { (Hook. f.) C.Y. Wu }\end{array}$ & Nanchuan, Congqing, China & $13,860,798$ & 241 & MT473779 \\
\hline Nepetoideae & Ocimeae & $\begin{array}{l}\text { Hanceola exserta Y.Z. Sun } \\
\text { ex C.Y. Wu }\end{array}$ & Hezhou, Guangxi, China & $67,557,758$ & 203 & MT473765 \\
\hline Nepetoideae & Ocimeae & $\begin{array}{l}\text { Isodon amethystoides (Benth.) } \\
\text { H. Hara }\end{array}$ & Lin'an, Zhejiang, China & $25,146,824$ & 696 & MT473767 \\
\hline Nepetoideae & Ocimeae & $\begin{array}{l}\text { Isodon lophanthoides (Buch.-Ham. } \\
\text { ex D. Don) H. Hara }\end{array}$ & Kunming, Yunnan, China & $40,730,966$ & 316 & MT473768 \\
\hline Nepetoideae & Ocimeae & Isodon ternifolius (D. Don) Kudô & Longling, Yunnan, China & $32,984,960$ & 542 & MT473769 \\
\hline
\end{tabular}


Table 1 Newly sampled species in this study (NA data unavailable) (Continued)

\begin{tabular}{|c|c|c|c|c|c|c|}
\hline \multicolumn{2}{|c|}{ Systematic assignment } & \multirow{2}{*}{$\begin{array}{l}\text { Species } \\
\text { Coleus xanthanthus C.Y. Wu \& } \\
\text { Y.C. Huang }\end{array}$} & \multirow{2}{*}{$\begin{array}{l}\text { Locality } \\
\text { Mengla, Yunnan, China }\end{array}$} & \multirow{2}{*}{$\begin{array}{l}\text { Clean reads } \\
25,669,120\end{array}$} & \multirow{2}{*}{$\begin{array}{l}\begin{array}{l}\text { Mean } \\
\text { coverage } \\
\text { of base }(\mathbf{x})\end{array} \\
821\end{array}$} & \multirow{2}{*}{$\begin{array}{l}\begin{array}{l}\text { GenBank } \\
\text { accession } \\
\text { numbers }\end{array} \\
\text { MT473748 }\end{array}$} \\
\hline Nepetoideae & Ocimeae & & & & & \\
\hline Nepetoideae & Menheae & Dracocephalum taliense Forrest & Heqing, Yunnan, China & $68,863,176$ & 446 & MT473756 \\
\hline Nepetoideae & Menheae & $\begin{array}{l}\text { Clinopodium abyssinicum (Benth.) } \\
\text { Kuntze }\end{array}$ & Kabarnet, Baringo, Kenya & $48,657,815$ & 833 & MT473747 \\
\hline Peronematoideae & - & Garrettia siamensis H.R. Fletcher & Mengla, Yunnan, China & $69,566,486$ & 1905 & MT473760 \\
\hline Peronematoideae & - & Hymenopyramis cana Craib & Changjiang, Hainan, China & $66,946,216$ & 298 & MT473766 \\
\hline Premnoideae & - & Premna szemaoensis C. P'ei & Kunming, Yunnan, China & $69,409,616$ & 477 & MT473775 \\
\hline Premnoideae & - & Premna vietnamensis $\mathrm{Bo} \mathrm{Li}$ & K'Bang, Gia Lai, Vietnam & $80,675,070$ & 460 & MT473774 \\
\hline Premnoideae & - & Gmelina arborea Roxb. ex Sm. & Mengla, Yunnan, China & $67,974,942$ & 493 & MT473761 \\
\hline Premnoideae & - & Gmelina hainanensis Oliv. & Kunming, Yunnan, China & $67,354,640$ & 1527 & MT473762 \\
\hline Premnoideae & - & Gmelina philippensis Cham. & Mengla, Yunnan, China & $69,953,046$ & 479 & MT473763 \\
\hline Prostantheroideae & Chloantheae & Chloanthes coccinea Bartl. & $\begin{array}{l}\text { Australian National Botanic } \\
\text { Gardens (ANBG), Australia }\end{array}$ & $81,265,290$ & 598 & MT473744 \\
\hline Prostantheroideae & Chloantheae & $\begin{array}{l}\text { Dasymalla teckiana (F. Muell.) } \\
\text { B.J. Conn \& Henwood }\end{array}$ & $\begin{array}{l}\text { Australian National Botanic } \\
\text { Gardens (ANBG), Australia }\end{array}$ & $41,308,508$ & 519 & MT473754 \\
\hline Prostantheroideae & Chloantheae & Dicrastylis parvifolia F. Muell. & $\begin{array}{l}\text { Australian National Botanic } \\
\text { Gardens (ANBG), Australia }\end{array}$ & $81,081,410$ & 577 & MT473755 \\
\hline Symphorematoideae & - & Congea tomentosa Roxb. & Mengla, Yunnan, China & $40,494,132$ & 110 & MT473752 \\
\hline Symphorematoideae & - & Sphenodesme mollis Craib & Mengla, Yunnan, China & $81,008,454$ & 529 & MT473780 \\
\hline Tectonoideae & - & Tectona grandis L. f. & Mengla, Yunnan, China & $40,169,710$ & 514 & MT473781 \\
\hline Viticoideae & - & Vitex glabrata R. Br. & Mengla, Yunnan, China & $70,126,282$ & 722 & MT473782 \\
\hline Viticoideae & - & $\begin{array}{l}\text { Vitex negundo var. cannabifolia } \\
\text { (Siebold \& Zucc.) Hand.-Mazz. }\end{array}$ & Kunming, Yunnan, China & $67,083,468$ & 1387 & MT473783 \\
\hline Viticoideae & - & Vitex quinata (Lour.) F.N. Williams & Mengla, Yunnan, China & $69,282,366$ & 828 & MT473784 \\
\hline Viticoideae & - & Vitex tripinnata (Lour.) Merr. & $\begin{array}{l}\text { Guangzhou, Guangdong, } \\
\text { China }\end{array}$ & $67,065,514$ & 1404 & MT473785 \\
\hline Viticoideae & - & Vitex yunnanensis W.W. Sm. & Luquan, Yunnan, China & $70,217,642$ & 395 & MT473786 \\
\hline
\end{tabular}

(Fig. 1) for the following discussion of phylogenetic relationships.

Within Lamiaceae, two primary clades were recovered and subdivided as 12 clades corresponding to the 12 subfamilies (Fig. 1), with each subfamily being monophyletic (excepting Cymarioideae, which was represented by only one species). The first clade comprised the Prostantheroideae and Callicarpoideae (i.e., Calliprostantherina sensu Li et al. [19]), both with strong support (MLBS $=100 \%$, $\mathrm{BIPP}=1.00$; Fig. 1; Additional files 4, 5, 6, 7: Figs. S2, S3, S4, S5, and all support values follow this order hereafter). The two tribes of Prostantheroideae, Chloantheae and Westringieae, were each recovered as monophyletic and sister taxa with strong support $(100 \%, 1.00)$. The second clade of Lamiaceae consisted of Nepetoideae, Symphorematoideae, Viticoideae, Tectonoideae, Premnoideae, Ajugoideae, Peronematoideae, Scutellarioideae, Cymarioideae, and Lamioideae (Fig. 1; Additional files 4, 5, 6, 7: Figs. S2, S3, S4, S5).
Within Nepetoideae (100\%, 1.00), the monophyly of Elsholtzieae, Ocimeae, and Mentheae was robustly supported in all analyses $(100 \%, 1.00)$. However, relationships among the three tribes varied among different datasets. Most of the datasets (CRM, CR, CR3, dePCS) supported Elsholtzieae as sister to Ocimeae (Fig. 1, 86\%, 1.00; Additional files 4, 5: Figs. S2, S3; Additional file 7: Fig. S5), while in the phylogeny based on dataset CR12, Elsholtzieae were weakly supported as sister to Mentheae (Additional file 6: Fig. S4, 45\%, 0.66).

In tribe Elsholtzieae, the genus Elsholtzia Willd. was recovered as sister to Collinsonia L. and Perilla L., and the sister relationships received maximal support in all analyses (Fig. 1; Additional files 4, 5, 6, 7: Figs. S2, S3, S4, S5). Representatives of all seven subtribes of Ocimeae formed a well-resolved clade, with subtribe Siphocranioninae (Siphocranion spp.) diverging first, followed by subsequent bifurcations for subtribes Lavandulinae (Lavandula spp.), Hanceolinae (Hanceola exserta Y.Z. 
Table 2 Data characteristics with models selected for each dataset used for phylogenetic study in the present study

\begin{tabular}{|c|c|c|c|c|c|}
\hline Dataset & CRM & CR & CR12 & CR3 & dePCS \\
\hline GC content & $38.3 \%$ & $38.3 \%$ & $40.2 \%$ & $34.5 \%$ & $30.8 \%$ \\
\hline Alignment sites (bp) & 69,822 & 72,082 & 48,069 & 24,013 & 72,082 \\
\hline Constant sites (bp) & 41,459 & 43,415 & 31,083 & 12,331 & 50,977 \\
\hline Parsimony-informative sites (bp) & 29,945 & 20,185 & 11,561 & 8,624 & 14,473 \\
\hline Variable sites (bp) & 28,363 & 28,667 & 16,986 & 11,682 & 21,105 \\
\hline Missing data & $4.31 \%$ & $4.31 \%$ & $4.31 \%$ & $4.31 \%$ & $4.31 \%$ \\
\hline Best-fit model & $\mathrm{GTR}+\mathrm{I}+\mathrm{G}$ & $\mathrm{GTR}+\mathrm{I}+\mathrm{G}$ & $\mathrm{GTR}+\mathrm{I}+\mathrm{G}$ & $\mathrm{GTR}+\mathrm{I}+\mathrm{G}$ & $\mathrm{GTR}+\mathrm{G}$ \\
\hline
\end{tabular}

Sun ex C.Y. Wu), Isodoninae (Isodon spp.), Hyptidinae (Mesosphaerum suaveolens (L.) Kuntze), Ociminae (Ocimum spp.), and Plectranthinae (Coleus spp.). Relationships within tribe Mentheae were also well resolved $(100 \%, 1.00)$, with subtribe Salviinae recovered as sister to the remaining four subtribes, Prunellinae, Lycopinae, Menthinae, and Nepetinae.

Along the backbone of the tree, subsequent to the branching of the Nepetoideae, Symphorematoideae $(100 \%, 1.00)$ and Viticoideae $(100 \%, 1.00)$ formed a clade (i.e., Viticisymphorina sensu Li et al. [19]), which was followed by subsequent bifurcation supporting clades of the Tectonoideae $(100 \%, 1.00)$, Premnoideae $(100 \%$, 1.00), and then Ajugoideae, respectively (Fig. 1, 100\%, $1.00)$. Ajugoideae $(100 \%, 1.00)$ were divided into four subclades that corresponded with the structure of tribal classification: each tribe was recovered as monophyletic and provided with high branch support $(100 \%, 1.00)$. Within the Ajugoideae, Rotheceae were recovered as sister to the Teucrieae, Clerodendreae, and Ajugeae.

The sister clade of Ajugoideae was comprised of Peronematoideae, Scutellarioideae, Cymarioideae, and Lamioideae (i.e., the phylogenetically defined Perolamiina in Li et al. [19]). Monophyly of Ajugoideae plus Perolamiina was supported in all analyses with moderate support values (Fig. 1, 71\%, 0.98; Additional files 4, 5, 6, 7: Figs. S2, S3, S4, S5), and Peronematoideae were recovered as monophyletic $(100 \%, 1.00)$ and sister to Scutellarioideae + Cymarioideae + Lamioideae (i.e., Scutelamiina sensu Li et al. [19]). Within Scutellarioideae, four out of five genera were included for analyses and the monotypic genus Wenchengia C.Y. Wu \& S. Chow $(100 \%, 1.00)$ is sister to the remaining three genera $(100 \%, 1.00)$. The sister clade of Scutellarioideae consisted of Cymarioideae and Lamioideae (100\%, 1.00). Within Lamioideae, Pogostemoneae were the earliest diverging lineage, followed by the Gomphostemmateae, Colquhounieae, Synandreae, Betoniceae, Galeopseae, Stachydeae, Paraphlomideae, Phlomideae, Leonureae, Marrubieae, Leucadeae, and Lamieae; consistent with previously published studies [52, 53], most tribes received maximal support values, although some tribes were only represented by a limited number of species (e.g., Lamieae, Leucadeae, and Leonureae).

\section{Discussion}

It has been more than 20 years since the first attempt was made to employ molecular data as evidence to infer a phylogenetic tree for Lamiaceae, which made use of the $r b c L$ region of the chloroplast genome [15]. Subsequently, various phylogenetic analyses have greatly contributed to our understanding of the circumscription, classification, and phylogeny of this family, progressively improving the resolution of relationships $[15,19,25$, $27-31,44,46,52-54,69]$. This study, based on coding plastome sequences, provides the most comprehensive phylogeny of Lamiaceae at the tribal level to date. With increased taxon sampling and a vastly expanded DNA dataset, the results of our plastid phylogeny significantly clarify the remaining ambiguities for all relationships among subfamilies and provide better support for all nodes in the phylogenetic tree at the subfamilial level.

In our phylogenetic analyses, 12 subfamilies are recovered and well-supported as monophyletic (Fig. 1; Additional files 4, 5, 6, 7: Figs. S2, S3, S4, S5). Our results correspond with the most recent phylogenetic study using five cpDNA regions [19] and have resolved the placement of the Nepetoideae, Premnoideae, and Ajugoideae which were previously unknown. Nepetoideae, the largest subfamily of Lamiaceae, is sister to a grade of lineages comprising the Symphorematoideae, Viticoideae, Tectonoideae, Premnoideae, Ajugoideae, Peronematoideae, Scutellarioideae, Cymarioideae, and Lamioideae (Fig. 1). However, our results differ somewhat from those of the Mint Evolutionary Genomics Consortium [20], which used 520 single-copy nuclear genes from 48 Lamiaceae species representing 11 of 12 subfamilies. Their results of the first-diverging lineages were consistent with ours and only differ within the clade of Premnoideae, Ajugoideae, Peronematoideae, Scutellarioideae, Cymarioideae, and Lamioideae, where most of the relationships in their tree were weakly supported. Furthermore, taxon sampling was sparse in their study, and it is possible that additional taxon sampling 


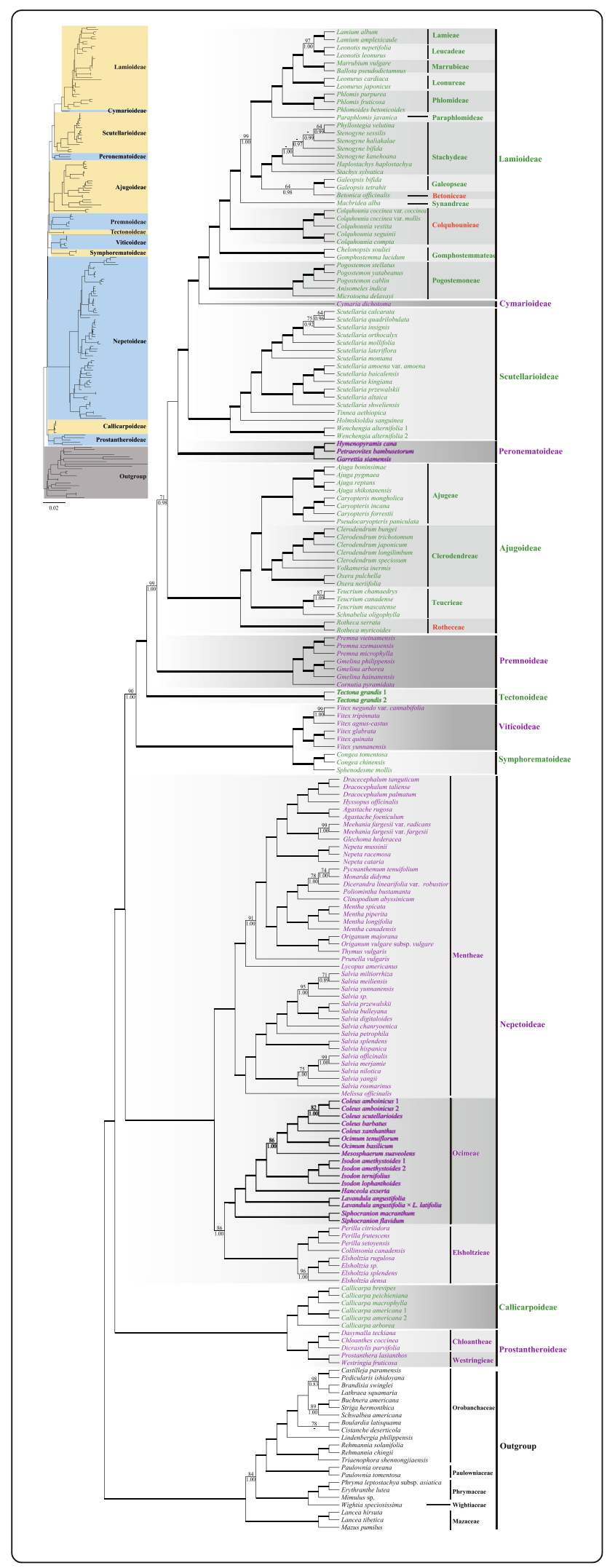

Fig. 1. Maximum likelihood phylogeny of Lamiaceae based on combined 79 plastid coding regions dataset, with ambiguously aligned sites excluded. Maximum likelihood bootstrap support (MLBS) and Bayesian inference posterior probability (BIPP) are shown above and below the branches, respectively. Bold horizontal lines indicate clades with BIPP $=1.00$ ) and $\mathrm{MLBS}=100 \%$. A " - " indicates MLBS values $<50 \%$ and BIPP $<0.8$. Subfamilies and tribes recognized by Li et al. [19] and Li and Olmstead [51] are indicated by gray boxes, while new tribes proposed in this study were marked in red font

could alter the subfamilial relationships that their analyses recovered.

Relationships within Lamioideae are also relatively similar with previous broad-scale studies [52, 53], but internal support values from our study are generally higher. Within Lamioideae, five genera (Betonica, Colquhounia, Galeopsis, Metastachydium, and Roylea) have not previously been assigned tribal status [2, 52, 53]. In addition, the phylogenetic position of Paralamium remains unclear $[2,53]$, since the genus has not been included in any published molecular phylogenetic study. We included three of these genera (Betonica, Colquhounia, and Galeopsis) in our study.

Colquhounia is recovered as sister (Fig. 1, 100\%, 1.00) to the clade of Synandreae, Betoniceae, Galeopseae, Stachydeae, Paraphlomideae, Phlomideae, Leonureae, Marrubieae, Leucadeae, and Lamieae. The morphological distinctiveness and well-supported phylogenetic position of Colquhounia substantiates tribal recognition within Lamioideae as tribe Colquhounieae (see "Taxonomic treatment").

Corroborating previous phylogenetic studies [52, 53], our chloroplast phylogeny demonstrates that Galeopsis and Betonica form a clade (Fig. 1, 64\%, 0.98) that is sister to the Stachydeae $(100 \%, 1.00)$. This clade in turn is recovered as sister to a clade of Paraphlomideae, Phlomideae, Leonureae, Marrubieae, Lamieae, and Leucadeae. Using cpDNA markers, Scheen et al. [52] and Bendiksby et al. [53] found this same structure, and our unpublished data based on chloroplast DNA markers (M. Bendiksby and Y. Salmaki, in prep.) also suggests these two genera occupy different positions within Lamioideae. In contrast, analyses using the low-copy nuclear pentatricopeptide repeat $(P P R)$ region recovered Galeopsis as sister to tribe Synandreae rather than sister to Betonica, albeit this was provided with low support [69]. With the available evidence (see "Discussion"), the phylogeny supports that Betonica and Galeopsis are distinct from other tribes. As suggested by Li and Olmstead [51], "for the benefit of those who need a complete, rank-based classification of Lamiaceae to arrange genera and species in checklists", a new monotypic tribe (i.e., Betoniceae) is established here and the tribe Galeopseae (also monotypic) is resurrected, to accommodate the 
systematic positions of these two genera within Lamioideae. The tribal placement of the remaining three genera, Paralamium, Roylea, and Metastachydium, is still uncertain.

Within Ajugoideae, we recover the same relationships as reported by Xiang et al. [54], who sampled 51 taxa representing 22 of the 23 genera of the subfamily and identified four main clades. All clades are recovered as monophyletic and receive better resolution (Fig. 1). Although Xiang et al. [54] improved our understanding of relationships within Ajugoideae, a tribal classification scheme for the subfamily has been needed. Corroborating previous studies [54], we propose a formal tribal classification for subfamily Ajugoideae, including the new tribe Rotheceae (see "Taxonomic treatment").

The advances in our knowledge reported in the results above cement a foundation in our understanding of relationships within Lamiaceae. In order to provide a clearer picture in light of these results and to consolidate the numerous advances made in the systematics of Lamiaceae since Harley et al. [1], the following sections provide a detailed discussion and commentary for each subfamily and tribe.

\section{Subfamily Prostantheroideae Luerss.}

Prostantheroideae consist of approximately 315 species allocated to two tribes: Chloantheae and Westringieae. They are distinguished from all other subfamilies by having a prominent albuminous seed $[4,8]$. While multiple cell layers can be found in the endosperm in other subfamilies [70] (therefore technically albuminous), the endosperm never develops to a size that can be easily seen [1].

Although confined to Australia, Prostantheroideae are widely distributed throughout most of the continent, in both temperate and tropical climates. Within this expanse, the habitats they occupy range from riparian zones of cool temperate rainforest to crests of shifting sand dunes in the central arid region.

Prostantheroideae are sister to Callicarpoideae (i.e., Calliprostantherina sensu Li et al. [19]). This relationship was first discovered by Olmstead et al. [71], then consistently supported by subsequent molecular phylogenetic studies [18-20, 31, 72] as well as our own (Fig. 1; Additional files 4, 5, 6, 7: Figs. S2, S3, S4, S5). Together, both Prostantheroideae and Callicarpoideae form a sister clade to the remaining Lamiaceae (Fig. 1) [18-20, 31, 72]. In addition to having albuminous seeds, Prostantheroideae are distinguished from Callicarpoideae by their dry fruits (vs. fleshy fruits).

\section{Tribe Chloantheae Benth. \& Hook.f}

Chloantheae consist of 13 genera and ca. 100 species of shrubs (or subshrubs) distributed across mainland Australia
[73]. This distribution includes a large number of species adapted to extreme arid habitats, with genera such as Newcastelia F. Muell. and Dicrastylis Drumm. ex Harv. occupying sandy deserts of the central inland [74].

A remarkable diversity in floral morphology is displayed across Chloantheae, with corollas ranging from 5-merous and zygomorphic (e.g., Chloanthes R. Br. and Dasymalla Endl.) to 5-8 (-10)-merous and actinomorphic (e.g., Dicrastylis). All species are distinguished (particularly from the sister tribe Westringieae) by an unlobed ovary, which develops into a $1(-2)$ seeded dry indehiscent fruit [1], and a distinctive indumentum of complex dendritic trichomes (typically tomentose) covering branches, leaves, and flowers (except four species in the Westringieae).

Many taxonomic changes have been made for Chloantheae and its constituents. Since the description of Chloanthes and Pityrodia R. Br. [75], most genera were shuffled between different tribes of Verbenaceae $[76$, 77]. Most were allocated within the tribe Chloantheae (Verbenaceae) by Bentham [4]. This treatment was followed later by Hutchinson's recognition as family Chloanthaceae [78], which was accepted by some authors [74, 79-83], but not all [84, 85].

Phylogenetic analysis of morphological [9] and molecular data [71] indicated that Chloantheae is sister to Westringieae within Lamiaceae, which is supported here (Fig. 1). The contemporary understanding of generic relationships within the tribe was informed by the comprehensively sampled molecular phylogeny of Conn et al. [24], which found that Pityrodia was not monophyletic, precipitating the description of Muniria N. Streiber \& B.J. Conn and restoration of Dasymalla and Quoya Gaudich. [73]. Another new genus, Apatelantha, was recently described to accommodate a clade identified by Conn et al. [24] composed of individuals formerly assigned to Lachnostachys Hook., Newcastelia, and Physopsis Turcz. [86]. Although our study only samples three taxa in Chloantheae, as in previous studies [73], it supports the close relationship between Dasymalla and Chloanthes relative to Dicrastylis (Fig. 1; Additional files 4, 5, 6, 7: Figs. S2, S3, S4, S5).

\section{Tribe Westringieae Bartl.}

Westringieae consist of five genera and over ca. 210 species of subshrubs, shrubs, and small trees distributed across Australia [1]. Frequently found restricted to exposed and rocky or well-drained places, members of the tribe are distributed throughout habitats within which these places occur, from rainforests to ranges of the Australian arid inland.

Flowers are 5-merous and weakly to strongly zygomorphic, similar to bird or insect pollination syndromes typically found in other Lamiaceae [87-89]. The tribe 
can be distinguished from Chloantheae by a four-lobed ovary, which develops into four nutlets [1]. The variation in anther morphology (e.g., outgrowth of the antheridial connective of Prostanthera Labill.) combined with reductions in fertility (reduction of abaxial stamens to staminodes in Westringia Sm.) in this tribe distinguishes it from Chloantheae (which typically has four bithecate anthers) and assists with informing the contemporary generic delimitation in the tribe $[1,90]$.

Tribal recognition of Westringieae and its generic constituency was first described by Bentham [91]. The monophyly of this tribe, in addition to its sister relationship to Chloantheae, has been substantiated by numerous phylogenetic analyses $[9,19,71]$ including our own (Fig. 1). Further investigation into generic relationships has shown that Hemiandra R. Br., Hemigenia R. Br., Microcorys R. Br., and Westringia are closely related to each other with respect to Prostanthera [87, 90, 92], although the relationship between them still needs to be resolved by more comprehensively sampled phylogenetic studies.

\section{Subfamily Callicarpoideae Bo Li \& R.G. Olmstead}

This recently described subfamily consists only of the genus Callicarpa which contains ca. 170 species of small trees or shrubs primarily distributed in tropical to temperate Asia, tropical and subtropical America, Australia, and some Pacific Islands [19, 51]. Callicarpoideae differs from other subfamilies by having a peltate or capitate stigma and a drupaceous fruit with four stony pyrenes [51]. Furthermore, Callicarpoideae possess actinomorphic flowers which are unusual within Lamiaceae (generally zygomorphic). The group is remarkably morphologically homogeneous given its broad geographical distribution, although there is variation in the number of flower parts and stamen structure among different species within Callicarpoideae.

Callicarpa was historically placed in Verbenaceae and treated as a member of tribe Callicarpeae in subfamily Viticoideae [5]. It was first transferred to Lamiaceae based on a cladistic analysis of morphological, anatomical, and palynological characters $[9,10]$ and later confirmed by molecular study [19]. Because only one or few representatives of the genus were included, different phylogenetic analyses resolved Callicarpa in different positions within Lamiaceae [19, 31, 52, 53, 71].

The sister relationship between Callicarpa and Prostantheroideae was first discovered by Olmstead et al. [71] and confirmed by subsequent studies [18-20, 31, 72]. In our analyses, they form a well-supported clade, which is sister to the remaining Lamiaceae (Fig. 1; Additional files 4, 5, 6, 7: Figs. S2, S3, S4, S5).

\section{Subfamily Nepetoideae (Dumort.) Luerss.}

Nepetoideae are the most species-rich subfamily within Lamiaceae, with about 3400 species divided into three tribes, Elsholtzieae, Mentheae, and Ocimeae [1]. Nepetoideae are native to every continent except Antarctica and are found in each of the seven global regions of high Lamiaceae diversity $[1,93]$. Although only clarified when comparative pollen analyses were established $[6,8]$, Nepetoideae are now considered among the most clearly defined subfamilies of Lamiaceae and have consistently been supported as monophyletic in molecular analyses $[15,19,31,44,94,95]$. Nepetoideae contain nearly all the aromatic species within Lamiaceae and are characterized by hexacolpate, trinucleate pollen $[6,8]$, an investing embryo [96], and the presence of rosmarinic acid [1]. Additionally, mucilaginous nutlets are only known to occur in the Nepetoideae within Lamiaceae and occur in all three tribes [97]. Thus, mucilaginous nutlets may also represent a synapomorphy within Nepetoideae.

The tribal assignment for groups now in Nepetoideae has been controversial $[4,5,7]$ and was summarized by Cantino [10]. Results from morphological and molecular studies $[9,10,95]$ led to a fundamentally new tribal classification for Nepetoideae proposed by Cantino et al. [11]. They recognized the four tribes Elsholtzieae, Ocimeae, Lavanduleae, and Mentheae, with the latter containing the largest number of changes in circumscription. Harley et al. [1] basically adopted this treatment of Cantino et al. [11], with the exception of subsuming Lavanduleae within Ocimeae. Although the three tribes of Harley et al. [1] are well-supported in both previous studies [16, 23, 27, 31, 98] and our analyses (Fig. 1; Additional files 4, 5, 6, 7: Figs. S2, S3, S4, S5), relationships among the three tribes remain murky. Previous studies have either found (1) Ocimeae to be sister to the Mentheae-Elsholtzieae clade [95], or (2) Mentheae to be sister to the Ocimeae-Elsholtzieae clade $[16,23,27,98]$, or (3) Elsholtzieae to be sister to the Mentheae-Ocimeae clade [31]. Our results reveal that Elsholtzieae is sister to Ocimeae in most of the analyses (CRM, CR, CR3, dePCS) (Fig. 1; Additional files 4, 5, 7: Figs. S2, S3, S5), but is weakly supported as sister to Mentheae by the dataset CR12 (Additional file 6: Fig. S4). Since none of the abovementioned relationships are strongly supported, nor a broad sampling within all three tribes are included in these studies, further studies are still needed to resolve the relationships among the three tribes.

\section{Tribe Elsholtzieae (Burnett) R.W. Sanders \& P.D. Cantino}

Elsholtzieae are the smallest tribe of Nepetoideae, comprising eight genera and ca. 70 species mostly distributed across East and Southeast Asia. Collinsonia, which is 
restricted to eastern North America, is the sole New World member of this tribe $[1,98]$. Species of Elsholtzieae share divergent stamens, a weakly 2 -lipped corolla, and an asymmetric disc with an elongate anterior lobe, but it is unclear whether these features are apomorphic $[1,31]$.

The tribe was formally validated by Sanders and Cantino [99] and consisted of six genera in the classification of Cantino et al. [11]: Collinsonia, Elsholtzia, Keiskea Miq., Mosla (Benth.) Buch.-Ham. ex Maxim., Perilla, and Perillula Maxim. In the molecular phylogenetic study of Nepetoideae by Wagstaff et al. [95], Elsholtzieae was represented by Elsholtzia, Collinsonia, and Perilla and formed a well-supported clade. Based on a sampling of all genera of Elsholtzieae using two nrDNA and four cpDNA markers, the results by Chen et al. [31] confirmed that the previously incertae sedis genus Ombrocharis is a member of the tribe and sister to Perillula. Contemporaneously, based on results from molecular phylogenetic analyses [31] and karyological studies [100], Mayta-Anco et al. [101] established a new genus, Vuhuangia Solomon Raju, Molinari \& Mayta, to accommodate Elsholtzia flava (Benth.) Benth. and E. penduliflora W.W. Sm. However, Li et al. [98], apparently unaware of Vuhuangia, demonstrated that Elsholtzia was not monophyletic and outlined E. flava and E. penduliflora should be separated from Elsholtzia as a distinct genus.

Biogeographic analysis of an expanded sample of Elsholtzieae showed that the tribe originated in East Asia and then dispersed to Southeast Asia and North America; the uplifts of the Qinghai-Tibetan Plateau and climate changes from Middle Miocene onwards may have promoted the species diversification of Elsholtzieae [98].

\section{Tribe Ocimeae Dumort.}

Ocimeae are characterized by declinate stamens lying along the anterior lip of the corolla and synthecous anthers [1, 102]. As currently circumscribed, a total of 43 genera and over 1200 species are included in Ocimeae, distributed mainly in the tropics and subtropics [1, 103, 104]. Major centers of diversity include tropical Africa and Madagascar, China and Malaysia, and South America $[1,103]$.

In early classifications of Lamiaceae [4, 5], Ocimeae were recognized as subfamily Ocimoideae. Based on an expansive morphological cladistic analysis, Cantino [9, 10] reduced Ocimoideae to tribe Ocimeae within subfamily Nepetoideae sensu Cantino et al. [11]. Ocimeae was further divided into three subtribes: Hyptidinae, Plectranthinae, and Ociminae [11]. Because Isodon (Schrad. ex Benth.) Spach, Hanceola Kudô, and Siphocranion Kudô are very different from other Ocimeae in terms of nutlet, inflorescence, and calyx morphology, Paton and Ryding [102] treated the three genera as incertae sedis within Ocimeae, while Harley et al. [105] later established subtribe Hanceolinae to accommodate them.

Paton et al. [23] carried out the first molecular phylogenetic analyses of Ocimeae and revealed that the genus Lavandula L. was sister to the remaining Ocimeae and thus subtribe Lavandulinae was recognized within Ocimeae [23]. However, the two genera Hanceola and Siphocranion were not included in their analysis. The phylogenetic relationships within Ocimeae were further elucidated based on more comprehensive sampling by Zhong et al. [106], who demonstrated that Siphocranion, Hanceola, and Isodon each formed a distinct lineage within Ocimeae. The subtribes Siphocranioninae and Isodoninae were thus described to accommodate Siphocranion and Isodon, respectively, while subtribe Hanceolinae only includes Hanceola [106].

Recently, Chen et al. [107] reported a new species of Siphocranion, and in their molecular phylogenetic analyses based on six cpDNA markers, Siphocranioninae is shown to be sister to the remaining subtribes, with Lavandulinae further supported as the sister group of the clade including Hanceolinae, the IsodoninaeHyptidinae clade, and the Plectranthinae-Ociminae clade. Our phylogenomic analyses largely confirm the results of Chen et al. [107], with the exception that Isodoninae is resolved as sister to the Hyptidinae-OciminaePlectranthinae clade (Fig. 1; Additional files 4, 5, 6, 7: Figs. S2, S3, S4, S5).

\section{Tribe Mentheae Dumort.}

Mentheae are characterized by stamens divergent or ascending (not declinate), a distinctly 2-lipped corolla (rarely weakly so), symmetric disc (if asymmetric and anterior lobe elongate, then corolla distinctly 2-lipped), and nutlets with an areolate abscission scar. Some of the most widely known medicinal and culinary plants are found within this group: mint, oregano, sage, savory, and thyme. Mentheae comprise both the largest number of genera and species of any tribe within Nepetoideae and Lamiaceae. Many of the plants in this group are of economic and ecological importance and thus have commonly attracted the attention of scientists. This has resulted in fundamentally differing taxonomic approaches at all taxonomic ranks, making it difficult to provide accurate numbers for genera (about 60) or species (at least 2000).

Due to the abovementioned fluidity regarding circumscription within Mentheae, the classification of Harley et al. [1] is regarded as the starting point for a modern subtribal classification. There, three subtribes were recognized, Menthinae, Nepetinae, and Salviinae, along with two genera of uncertain placement (Heterolamium C.Y. Wu and $\mathrm{Me}$ lissa L.). Since the treatment of Harley et al. [1], 
relationships within Menthinae have been greatly clarified based on molecular phylogenetic studies [25, 27, 108-110]. Drew and Sytsma [27] accommodated Cleonia L., Horminum L., and Prunella L. in Prunellinae and erected a new subtribe, Lycopinae, for the enigmatic genus Lycopus L. (a tribe Lycopeae was previously proposed [111]). Neoeplingia Ramamoorthy, Hiriart \& Medrano along with Melissa were transferred to Salviinae [27] while Hyssopus L. and the previously unplaced Heterolamium were included in Nepetinae based on morphological [112] and molecular results [27, 113]. The currently accepted number of subtribes is thus five. This is also well-supported by our analyses, where Salviinae is sister to the other four subtribes; among the remaining subtribes, Nepetinae and Menthinae are sister groups, with Prunellinae and Lycopinae as successive sister groups to Nepetinae and Menthinae (Fig. 1; Additional files 4, 5, 6, 7: Figs. S2, S3, S4, S5).

\section{Subfamily Symphorematoideae Briq.}

Symphorematoideae contain about 21 species in three genera of woody climbers, Congea Roxb., Sphenodesme Jack, and Symphorema Roxb., and occur mainly in tropical regions of Asia. Symphorematoideae are characterized by having capitate cymes surrounded by bracteoles which are often conspicuous, colorful, and accrescent, and incompletely 2-locular ovaries [19].

Historically, Symphorematoideae has been treated as a separate family with the same circumscription $[114,115]$ or (more commonly) as part of Verbenaceae $[5,116]$. It was first found to be related to Lamiaceae in the molecular era $[15,16]$, and then transferred to Lamiaceae and treated as a subfamily [1, 117]. Li et al. [19] were the first to include all three genera of Symphorematoideae in a comprehensive phylogenetic analysis of Lamiaceae based on chloroplast sequences, and Symphorematoideae was found to be monophyletic and sister to Viticoideae. Such a sister relationship was further recovered in phylogenetic analyses based on nuclear genes [20] and confirmed in our phylogenomic analyses using plastome sequences (Fig. 1; Additional files 4, 5, 6, 7: Figs. S2, S3, S4, S5).

\section{Subfamily Viticoideae Briq.}

Viticoideae currently include ca. 280 species in three genera: Vitex (250 spp.), Teijsmanniodendron Koord. (23 spp.), and Pseudocarpidium Millsp. (9 spp.). These genera are distributed predominantly in the Tropics with a few species of Vitex occurring in temperate regions of the Northern Hemisphere [19].

Viticoideae as defined by Briquet [5] were a heterogeneous group whose circumscription has shrunk dramatically. Segregated from traditional Viticoideae are three subfamilies, Callicarpoideae, Premnoideae, and Tectonoideae in the present classification, and part of
Ajugoideae and Scutellarioideae. Furthermore, the type genus of Viticoideae, Vitex, has expanded to include Paravitex H.R. Fletcher, Petitia Jacq., Tsoongia Merr., and Viticipremna H.J. Lam based on molecular studies $[19,42]$. Even though only three genera remain in Viticoideae as currently circumscribed, the intergeneric relationships are still questionable, with the positions of Teijsmanniodendron and Pseudocarpidium poorly resolved [19]. As mentioned above, the sister relationship between Viticoideae and Symphorematoideae is firmly supported, and the two subfamilies share several anatomical traits [19]. Morphologically, species of Viticoideae can be easily recognized by the palmately compound leaves and dry or fleshy drupes or schizocarps.

\section{Subfamily Tectonoideae Bo Li \& R.G. Olmstead}

Tectonoideae comprise only the three species of Tectona. They are large trees native to tropical Asia from India to Southeast Asia, but are widely cultivated and naturalized in Africa, Central and South America, and the Caribbean [51].

Tectona was originally placed in tribe Tectoneae of Viticoideae [5], but was revealed to be sister to a large clade comprising Lamioideae, Cymarioideae, Scutellarioideae, Peronematoideae, Ajugoideae, and Premnoideae [19]. The relationship is also confirmed by our analyses (Fig. 1; Additional files 4, 5, 6, 7: Figs. S2, S3, S4, S5). However, Tectona was recovered as sister to a larger clade including the aforementioned subfamilies (Cymarioideae not sampled) as well as Symphorematoideae and Viticoideae in an analysis using low-copy nuclear markers [20]. Regardless of phylogenetic position, Tectonoideae represents a genetically isolated clade in Lamiaceae and has a series of distinct morphological traits $[19,51]$.

\section{Subfamily Premnoideae Bo Li, R.G. Olmstead \& P.D. Cantino}

Premnoideae were recently established to include three former viticoid genera (Sensu Harley et al. [1]): Cornutia, Gmelina, and Premna [19], with the total species number estimated at about 150 (B. Li, pers. comm.). Nearly all species of this subfamily are woody shrubs, trees, or climbers, occurring mainly in Old World tropical to subtropical regions (Gmelina and Premna) and the New World Tropics (Cornutia) [19].

With the current circumscription, Premnoideae are well-supported in our phylogenomic trees (Fig. 1; Additional files 4, 5, 6, 7: Figs. S2, S3, S4, S5). However, in a phylogeny of Lamiaceae based on nuclear genes, Cornutia was not recovered in Premnoideae but was sister to the Lamioideae-Ajugoideae-Peronematoideae-Scutellarioideae clade [20,72]. In the analyses of $\mathrm{Li}$ et al. [19], the relationships among Premnoideae, Ajugoideae, 
and Lamioideae-Cymarioideae-Scutellarioideae-Peronematoideae were not well resolved, but in our phylogenomic analyses, Premnoideae are strongly supported to be sister to the clade comprising Lamioideae, Cymarioideae, Scutellarioideae, Peronematoideae, and Ajugoideae (Fig. 1; Additional files 4, 5, 6, 7: Figs. S2, S3, S4, S5).

\section{Subfamily Ajugoideae Kostel.}

Ajugoideae are the third-largest subfamily within Lamiaceae and contain about 770 species in 23 genera [19, 48, $54,118,119]$ distributed worldwide but most common in tropical regions [1]. A possible synapomorphy of Ajugoideae may be pollen with branched to granular columellae [9].

Briquet [5] first elevated tribe Ajugeae sensu Bentham [4] to subfamilial rank, which was followed by most subsequent treatments $[1,7,116,120]$. Circumscription of Ajugoideae, however, has changed considerably. The recognition of some subfamilies (i.e., Teucrioideae and Caryopteridoideae) that include many traditionally verbenaceous genera (e.g., Caryopteris Bunge, Clerodendrum L., Schnabelia Hand.-Mazz., and Teucrium L.) was untenable. These genera were later transferred to Ajugoideae based on molecular phylogenetic $[15,16]$ and morphological evidence [121].

A recent phylogenetic study that sampled 22 out of the 23 genera of Ajugoideae and used four cpDNA markers (matK, rbcL, trnL-trnF, and rps16) strongly supported the monophyly of Ajugoideae and identified four major clades [54]. Relationships among these clades are consistent with the results in our study.

Currently, no tribal classification has been assigned for Ajugoideae. Although some old tribal names have been proposed [5, 91, 122], the circumscription of Lamiaceae at that time was much narrower compared to our current understanding, and many genera now placed within Ajugoideae (e.g., Caryopteris, Clerodendrum, Rotheca, Schnabelia, Volkameria L.) were previously treated as members of Verbenaceae. Based on results from both the present and previous studies [19, 54], we suggest that the four clades be recognized as tribes Ajugeae, Clerodendreae, Teucrieae, and Rotheceae, with the last proposed here as a new tribe (see "Taxonomic treatment" below).

\section{Tribe Rotheceae}

Rotheceae are established as a new tribe (see "Taxonomic treatment" below) comprising four genera: Rotheca (60 spp.), Glossocarya Wall. ex Griff. (13 spp.), Discretitheca P.D. Cantino (1 sp.), and Karomia Dop. (9 spp.). The tribe is disjunctly distributed from Australia (Queensland) and tropical southern Asia to southern Africa. No non-molecular synapomorphy has been found for this tribe.
Rotheca, the largest genus in this tribe, was resurrected by Steane and Mabberley [123] to maintain the monophyly of the genus Clerodendrum [35]. In the present study, we demonstrate Rotheca to be sister to all other members of the subfamily, as reported by Yuan et al. [124]. Although only Rotheca was sampled here, a close relationship to the other three genera has been demonstrated previously [54]. Steane et al. [36] found Karomia to be sister to Rotheca based on $n d h F$ sequences, and this relationship was corroborated by Li et al. [19] based on five cpDNA markers. Xiang et al. [54] found that Karomia, Discretitheca, Glossocarya, and Rotheca formed a clade, but with moderate support. Discretitheca and Glossocarya were only first included in molecular phylogenetic analyses [54], and detailed morphological studies as well as molecular phylogenetic studies for these two genera are scarce and more studies are needed. As with Discretitheca and Glossocarya, only one species of Karomia (K. speciosa (Hutch. \& Corbishley) R. Fern.) has been included in previous molecular phylogenetic analyses [36, 54], although DNA sequences of two species have been reported (the additional species is K. tettensis (Klotzsch) R. Fern. which was used mainly for ecological analyses [125]). Overall, the systematic relationships within this tribe await to be fully clarified.

\section{Tribe Teucrieae Dumort.}

Teucrieae consist of ca. 260 species in three genera, Teucrium (ca. 250 spp.), Schnabelia (5 spp.), and Rubiteucris Kudô (2 spp.). The latter two genera are endemic to East Asia, while Teucrium has a subcosmopolitan distribution. A possible synapomorphy of the tribe is the confluence of anther thecae at anthesis, a feature that also characterizes Ajugeae, where it may have arisen independently.

Teucrium is the largest genus in this tribe. A previous phylogenetic study [48] suggested the inclusion of Oncinocalyx F. Muell., Spartothamnella Briq., and Teucridium Hook.f. in Teucrium, and this treatment was confirmed by Xiang et al. [54]. Although both Rubiteucris and Schnabelia are small genera, the taxonomy and systematic relationships of Rubiteucris and Schnabelia were not sufficiently resolved until recent molecular phylogenetic studies based on a broad sampling [48, 54]. Here, the monophyly of Teucrieae is strongly supported (Fig. 1; Additional files 4, 5, 6, 7: Figs. S2, S3, S4, S5).

\section{Tribe Ajugeae Benth.}

Ajugeae contain 79 species in six genera: Ajuga L. (ca. 50 spp.), Amethystea L. (1 sp.), Caryopteris (7 spp.), Pseudocaryopteris (Briq.) P.D. Cantino (3 spp.), Trichostema Gronov. (17 spp.), and Tripora P.D. Cantino (1 sp.). Ajuga is distributed primarily in Eurasia, 
Amethystea is widespread in temperate Asia [1], Trichostema is restricted to North America [126], and the remaining three genera are endemic to East Asia. A possible synapomorphy is the confluence of the anther thecae at anthesis (with a reversal in Caryopteris), a feature that also characterizes Teucrieae and may have arisen independently in the two tribes. In most other species of Ajugoideae and in most of the closest outgroups, the thecae remain separate at anthesis. However, it is equally parsimonious to hypothesize that confluent anther thecae are a synapomorphy of the clade comprising Ajugeae, Clerodendreae, and Teucrieae, with a subsequent reversal at the base of Clerodendreae.

The traditionally delimited genus Caryopteris [5, 54, $127]$ is polyphyletic $[9,128]$ and species previously included in Caryopteris have been distributed in six genera: Caryopteris, Discretitheca, Pseudocaryopteris, Rubiteucris, Schnabelia, and Tripora, of which three were placed in tribe Ajugeae, two belong to tribe Teucrieae, and one belongs to tribe Rotheceae. A sistergroup relationship between Tripora and Pseudocaryopteris was inferred in previous studies [54, 129, 130], but support values varied in different studies. The sister relationship between the North American genus Trichostema and the East Asian genus Caryopteris was also reported in many studies $[15,16,35,36,130,131]$. Although Ajuga is the largest genus in this tribe, no phylogenetic study has been carried out for the genus to date, and infrageneric relationships within this genus still need further investigation.

\section{Tribe Clerodendreae Briq.}

Clerodendreae consist of ca. 350 species in ten genera: Clerodendrum (ca. 150 spp.), Volkameria (30 spp.), Kalaharia Baill. (1 sp.), Amasonia L.f. (8 spp.), Tetraclea A. Gray (2 spp.), Aegiphila Jacq. (120 spp.), Ovieda L. (21 spp.), Oxera Labill. (21 spp.), Hosea Ridl. (1 sp.), and probably Monochilus Fisch. \& C.A. Mey. (2 spp.). Monochilus has not been included in any published molecular analysis, but based on a cladistic analysis of morphological data, Cantino [9] suggested a close relationship between Monochilus and Amasonia. Both genera usually have alternate to subopposite leaves, a rare feature in Lamiaceae. Monochilus was not included in the molecular results presented here but the presence of alternate to subopposite leaves suggests that Monochilus should be treated within tribe Clerodendreae. However, this relationship needs to be tested using molecular evidence.

Clerodendreae are pan-tropical/subtropical in distribution, predominantly distributed in the Americas, Africa, Asia, and Pacific Oceania. A probable synapomorphy for the tribe is a drupaceous fruit with four one-seeded pyrenes. In some species, the fruits split into four fleshy schizocarps. A similar fruit type is found in Rotheca
(Tribe Rotheceae), where it apparently evolved independently. The character polarity is not entirely clear because Premnoideae also have drupaceous fruits. However, the fruits of Premnoideae contain a single four-seeded pyrene instead of four one-seeded ones. The other closely related groups (subfamilies Peronematoideae, Scutellarioideae, Cymarioideae, and Lamioideae) have dry fruits [19].

In terms of the number of genera, this is the largest tribe within subfamily Ajugoideae. Previous molecular phylogenetic studies concentrated mainly on two genera, Clerodendrum [34-36, 124] and Oxera $[118,119]$. As a result of the disintegration of the traditionally defined Clerodendrum, some genera (i.e., Volkameria, Ovieda, Rotheca) were resurrected [34-36, 123, 124]. Species relationships within those genera, however, remain uncertain. In addition, relationships within the clade including Ovieda, Aegiphila, Clerodendrum, Tetraclea, Amasonia, Kalaharia, and Volkameria, require further study.

\section{Subfamily Peronematoideae Bo Li, R.G. Olmstead \& P.D. Cantino}

Peronematoideae were recently established to accommodate a well-supported clade comprising four small, mostly tropical Asian genera, Garrettia (1 sp.), Hymenopyramis (7 spp.), Peronema (1 sp.), and Petraeovitex (8 spp.), which are sister to a larger clade formed by subfamilies Scutellarioideae, Cymarioideae, and Lamioideae [19]. These four genera were previously placed in the subfamily Caryopteridoideae of Verbenaceae [5, 132, 133] and were all transferred to Lamiaceae by Cantino et al. [11], with Hymenopyramis placed in Viticoideae, Peronema and Petraeovitex in Teucrioideae, and Garrettia in Ajugoideae. However, all the four genera were treated as incertae sedis in Harley et al.'s classification of Lamiaceae [1].

In recent molecular phylogenetic studies, Garrettia was first inferred to be sister to a clade comprising Scutellarioideae, Acrymia, Cymaria, and Lamioideae [53], while the same sister relationship to an equivalent clade of the Scutellarioideae-Cymaria-Lamioideae clade (Acrymia was not sampled) was later found for a small well-supported clade comprised of Hymenopyramis, Petraeovitex, and Peronema [31, 44], as confirmed in our phylogenomic trees (Fig. 1; Additional files 4, 5, 6, 7: Figs. S2, S3, S4, S5). When Garrettia, Hymenopyramis, Petraeovitex, and Peronema were included in the same analysis, they grouped together in a highly supported clade that is sister to the Scutellarioideae-Cymarioideae-Lamioideae clade [19]. Morphologically, the four genera are very heterogeneous but do share some common traits as noted by Chen et al. [44] and Li et al. [19]. 


\section{Subfamily Scutellarioideae (Dumort.) Caruel}

Scutellarioideae consist of ca. 390 species in five genera: Holmskioldia Retz. (1 sp.), Wenchengia (1 sp.), Renschia Vatke (1 sp.), Tinnea Kotschy ex Hook. f. (19 sp.), and Scutellaria L. (ca. 360 spp.) [1, 9, 121]. Species numbers and distribution of these genera are extremely uneven. Scutellaria is the largest and most widely distributed genus, having a cosmopolitan distribution [1, 134, 135]. Tinnea is much smaller and is distributed in tropical and southern Africa. The monotypic genera Renschia, Wenchengia, and Holmskioldia are endemic to Somalia, Southeast Asia (Hainan Island of China, Vietnam), and subtropical Himalayan regions, respectively. Scutellarioideae is diagnosed by the following synapomorphic characters: pericarps with tuberculate or elongate processes [136], high densities of xylem fibers in the calyces [137], and thyrses with single-flowered cymes that form raceme-like inflorescences (but most species of Tinnea and Holmskioldia have cymose inflorescences).

Scutellarioideae had been thought to be sister to Lamioideae [31, 44], but with the separation of Cymarioideae from the Lamioideae [19], Scutellarioideae is sister to the Cymarioideae-Lamioideae clade. Based on previous studies and our phylogenomic results, Tinnea and Holmskioldia are successive sister groups to Scutellaria, with Wenchengia sister to the rest of Scutellarioideae $[15,16,19,31,44,66,136]$. However, relationships within Scutellarioideae remain unresolved because Renschia has never been included in a molecular phylogenetic study. To date, four phylogenetic studies have focused on Scutellaria [66, 138-140], but none included a comprehensive taxon sampling of the genus or of Scutellarioideae as a whole. Thus, relationships within Scutellaria still need to be addressed in future studies.

\section{Subfamily Cymarioideae Bo Li, R.G. Olmstead \& P.D. Cantino}

Cymarioideae were recently established to include two small genera that have previously been considered incertae sedis [1], Acrymia (1 sp.) and Cymaria (2 spp.), which are endemic to Southeast Asia.

Bendiksby et al. [53] found that Acrymia and Cymaria were the closest relatives of Lamioideae, which was supported by a subsequent study [44] but only with moderate support. $\mathrm{Li}$ et al. [19] further confirmed this relationship with high support values and consequently established a new subfamily, Cymarioideae, to accommodate the systematic position of the Acrymia-Cymaria clade. In the present study, Cymaria dichotoma Benth. is sister to Lamioideae in all analyses (Fig. 1; Additional files 4, 5, 6, 7: Figs. S2, S3, S4, S5).

Regarding the systematic placement of the AcrymiaCymaria clade, two different treatments are feasible [19]. The Acrymia-Cymaria clade could be treated as a separate subfamily or as a distinct tribe within Lamioideae; both options are acceptable based on the principle of monophyly. However, as suggested by Bendiksby et al. [53] and Chen et al. [44], the inclusion of Acrymia-Cymaria within Lamioideae would make the subfamily morphologically heterogeneous and difficult to diagnose. The apomorphy of axial monochasial cymes which defines Cymarioideae is especially distinct and is not found within Lamioideae. Thus, we concur with the approach of Li et al. [19] and recognize Cymarioideae as a subfamily here.

\section{Subfamily Lamioideae Harley}

Lamioideae are the second largest subfamily within Lamiaceae, containing about 1260 species in 62 genera, with a near-cosmopolitan distribution, though concentrated in Eurasia and northern to tropical Africa [52, 53, 69].

Considerable progress has been made in our understanding of subfamily Lamioideae in recent years. Since Harley et al. [1], one genus has been established (Rydingia Scheen \& V.A. Albert [141]), four genera have been resurrected (Acanthoprasium (Benth.) Spenn. [53]; Betonica [52]; Phlomoides Moench [142]; Pseudodictamnus Fabr. [33]), eight genera have been reduced to synonyms (Alajja Ikonn. and Sulaimania Hedge \& Rech. f. [53]; Lamiophlomis Kudô, Notochaete Benth., and Pseuderemostachys Popov [142]; Eremostachys Bunge [28]; Bostrychanthera Benth. [43]; Stachyopsis Popov \& Vved. [143]), and Holocheila, which was formerly treated as incertae sedis [1], has been shown to belong in Lamioideae [44]. Molecular phylogenies have also established that subfamily Cymarioideae is sister to Lamioideae [19].

A tribal classification of Lamioideae was the result of a molecular phylogeny based on cpDNA $[52,53]$. The ten tribes have been corroborated as monophyletic groups using nuclear [143] and low-copy nuclear markers [67]. Four genera remained unplaced in the tribal classification because they formed monogeneric clades [53, 67]; however, two new tribes, i.e., Colquhounieae and Betoniceae, are proposed here to accommodate the genera $\mathrm{Col}$ quhounia and Betonica, respectively. The monotypic Roylea has still not been attributed to a tribe. Roylea groups within tribe Marrubieae in some nuclear-based phylogenies, but not in all and not in phylogenies based on cpDNA data $[33,53,67,143]$. To date, only two genera, Metastachydium and Paralamium, have still not been included in molecular phylogenetic studies of Lamioideae, and their relationship with the other genera remains enigmatic.

\section{Tribe Pogostemoneae Briq.}

Pogostemoneae consist of 11 genera as currently circumscribed [44, 52, 53], including Achyrospermum 
Blume (25 spp.), Anisomeles R. Br. (26 spp. [144]), Craniotome Rchb. (1 $\mathrm{sp}$.$) , Colebrookea Sm. (1 \mathrm{sp}$.$) ,$ Comanthosphace S. Moore (4 spp.), Eurysolen Prain (1 sp.), Holocheila (1 sp.), Leucosceptrum Sm. (1 sp.), Microtoena Prain (19 spp.) [145], Pogostemon Desf. (80 spp.) [146, 147], and Rostrinucula Kudô. (2 sp.), and all genera are monophyletic $[44,52,53,145,148]$. Most genera of the tribe are distributed in East Asia to Southeast Asia, with three genera having a disjunct distribution between Asia and tropical Africa (Pogostemon, Achyrospermum, and Anisomeles). In addition, the monotypic genus Paralamium Dunn. is probably a member of Pogostemoneae based on the presence of small glossy nutlets [53].

Pogostemoneae were established by Briquet [5] and originally included seven genera (Elsholtzia, Comanthosphace, Keiskea, Pogostemon, Dysophylla Blume, Tetradenia Benth., and Colebrookea). Later, Kudô [149] and Press [150] circumscribed Pogostemoneae in a broad sense, adding 11 genera to the tribe $[11,52,150]$. A number of taxonomic and molecular phylogenetic studies $[11,19,52,53,148,150,151]$ have indicated that six genera should be excluded from this tribe and that Dysophylla should be merged with Pogostemon, as suggested by Hasskarl [152] and Press [150], leaving the present total of 11 genera.

Cantino [10] and Cantino et al. [11] proposed a subfamily named Pogostemonoideae to include Colebrookea, Comanthosphace, Leucosceptrum, Pogostemon, Rostrinucula, Anisomeles, and Eurysolen, but with hesitation regarding the two latter genera. Recent molecular phylogenetic studies have shown that Pogostemonoideae are sister to Lamioideae and have been included in that subfamily $[52,53]$. Our results recover tribe Pogostemoneae as sister to the clade contain all other members of Lamioideae (Fig. 1). Previous studies based on plastid DNA regions [52, 53] identified two well-supported clades within Pogostemoneae. One clade includes Eurysolen, Leucosceptrum, Rostrinucula, Comanthosphace, and Achyrospermum and is characterized by having dull and glandular nutlets, and the sclerenchyma region in the pericarp obsolete, indistinct, or absent. The second clade is composed of Colebrookea, Craniotome, Microtoena, Anisomeles, and Pogostemon. Within this clade, two subclades were recognized [53]. Colebrookea is the only genus within the first subclade. This subclade is distinctive by possessing nutlets that are hairy and with eglandular hairs at the apex, while the remaining genera formed a second subclade united by having glossy and glabrous nutlets. Morphological studies focusing on traditionally defined Pogostemoneae (i.e., Pogostemonoideae; $[153,154])$ identified some useful taxonomic characters. Subsequently, Scheen et al. [52], while not identifying any morphological synapomorphies, suggested that small and relatively glossy nutlets, pericarps (typically) lacking a sclerenchyma region [153, 154], generally long-exserted stamens with (usually) bearded filaments, a (generally) weakly 2-lipped corolla, and (generally) broad bracts are potentially useful morphological characters in defining the tribe. Further comparative morphological studies combined with wellsupported phylogenetic trees based on extensive sampling and additional nuclear loci will be necessary to determine synapomorphies for this tribe.

\section{Tribe Gomphostemmateae Scheen \& Lindqvist}

Gomphostemmateae were established by Scheen et al. [52] to include three genera, Gomphostemma Wall. ex Benth. (ca. 36 spp.), Chelonopsis Miq. (ca. 16 spp.), and Bostrychanthera (2 spp.), that are distributed in temperate to tropical East Asia [1, 155]. Since then, the genus Bostrychanthera was subsumed within Chelonopsis by Xiang et al. [43] based on morphological [156, 157] and molecular data [43] (see also Bongcheewin et al. [158]), thus leading to only two genera (Gomphostemma and Chelonopsis) currently retained in this tribe.

Gomphostemmateae were shown to be sister to a large group of Lamioideae in previous studies [52, 53], but these results were equivocal due to suboptimal support values. Here, we find the same relationship but with higher support values (Fig. 1). Possible synapomorphies for the tribe include pollen with branched columellae [159] and fibers in the mesocarp [160, 161]. However, pericarp structure has only been reported in a few species, and it is unclear whether unexamined species share these characters. Thus, future detailed morphological studies are needed.

\section{Tribe Colquhounieae}

Colquhounieae are newly established here to accommodate the enigmatic Colquhounia. The genus comprises approximately five species endemic to the Himalayan massif from Nepal and north India to southwest China and Vietnam. Morphologically, the genus is characterized by having nutlets winged at the apex, which is rare within subfamily Lamioideae [52]; besides Colquhounia, only some species of Chelonopsis have this character.

Based on trichome morphology, $\mathrm{Hu}$ et al. [162] classified the genus into two sections, Colquhounia sect. Simplicipili C.Y. Wu \& H.W. Li (including C. seguinii Vaniot) and C. sect. Colquhounia (all remaining species), but this classification was not supported by molecular phylogenetic results [43]. Although Scheen et al. [52] and Bendiksby et al. [53] found that Colquhounia occupied a phylogenetically distinct position within Lamioideae, they kept the genus unclassified at the tribal level, in part because only two species $(C$. coccinea Wall. and C. elegans Wall. ex Benth.) and only three markers 
(trnL-trnF, rps16, and matK) were used for phylogenetic reconstruction. In this study, five taxa were included for analyses and they form a distinct clade within Lamioideae. Thus, we describe this clade as a new tribe (see "Taxonomic treatment" below).

\section{Tribe Synandreae Raf.}

Synandreae were recircumscribed by Scheen et al. [163] to include the following five genera: Brazoria Englm. \& A. Gray (3 spp.), Macbridea Elliott ex Nutt. (2 spp.), Physostegia Benth. (12 spp.), Synandra Nutt. (1 sp.), and Warnockia M.W. Turner (1 sp.). The only morphological synapomorphy for the tribe is a raceme-like inflorescence with sessile or very shortly pedicellate flowers [52, 163]. All five genera are characterized by having villous stamen filaments, but this is also found in some members of tribe Pogostemoneae (e.g., Pogostemon, Anisomeles) and tribe Stachydeae [1] (Chamaesphacos Schrenk ex Fisch. \& C.A. Mey).

Previous studies involving cpDNA, nrDNA, and lowcopy nuclear markers failed to adequately discern the position of Synandreae within Lamioideae [52, 53, 69, 163, 164]. Our results provide strong support for the placement of Synandreae, with the caveat that only one representative was included (Fig. 1). Only two lamioid tribes include species with a North American distribution, Synandreae and Stachydeae. The two tribes are not closely related $[52,53,69]$ and therefore represent separate dispersals into North America [163].

\section{Tribe Betoniceae}

Betoniceae are newly established here to accommodate the phenetically and genetically isolated genus Betonica in Lamioideae. There are nine currently accepted Betonica species, three of which include 2-6 subspecific taxa distributed throughout Europe reaching Central Asia and Northwest Africa [165]. Betonica has repeatedly been included in, and excluded from, the genus Stachys L. Some authors have treated Betonica as a distinct genus [166-171], while Bentham [90] and Briquet [5] placed Betonica in its own section within Stachys. In the most recent morphological classification of Stachys, Bhattacharjee [172] recognized Betonica as a subgenus (S. subg. Betonica (L.) Bhattacharjee) within Stachys, defined by prominent sterile rosettes, usually unbranched flowering shoots arising from an axillary bud of the rootstock, and deeply crenate to serrate leaf margins; features that Betonica shares with the Stachys sections Eriostomum (Hoffmanns. \& Link) Dumort. and Ambleia Benth. Yet, Bhattacharjee [172] mentions that S. subg. Betonica is divergent in the nature of the calyx (sessile calyx) and bracteoles (with a broad hardened base). Tomas-Bárberán et al. [173] points to differences in phytochemistry between Betonica and Stachys species, as currently circumscribed. Recently, Giuliani and Bini [174] found that Betonica possesses only peltate trichomes, while Stachys has different types of large capitate hairs that are lacking in Betonica. In addition, Giuliani and Bini [174] also found that peltate trichomes of Betonica species have unusual secretions composed of flavonoids and essential oils and suggested that Betonica should be considered a genus of its own.

An early molecular phylogenetic analysis of Stachys s.l. [39] based on both plastid and nuclear DNA sequence data demonstrated that the type species of Betonica, $B$. officinalis L. (as Stachys officinalis (L.) Trevis.), fell outside of the clade that contained the remainder of Stachys including the type species, S. sylvatica L. Perhaps not being aware of this, Harley et al. [1] retained Betonica in synonymy under Stachys. Since then, further molecular phylogenetic evidence has corroborated the distinctness of Betonica [52, 53, 69]. Based on results from a comprehensive plastid phylogeny of Lamioideae that included five species of Betonica, Scheen et al. [52] suggested Betonica should be resurrected from synonymy under Stachys. The five species of Betonica formed a strongly supported clade sister to Galeopsis, the sister relationship, however, receiving low statistical support. This phylogenetic result was corroborated by a follow-up study with more taxa and additional genetic markers [53]. The monophyly and distinctness of Betonica has received support also from nuclear data [69], with a weakly supported sister relationship to tribe Synandreae. Since Betonica so far has remained unclassified at the tribal level, and the genus seems to lack a clear affinity to any other lamioid taxon, we propose herein that the Betonica clade be recognized at the tribal level (see "Taxonomic treatment" below).

The intrageneric classification of Betonica into three sections $[175,176]$ (i.e., B. sect. Betonica, B. sect. Foliosae (Krestovsk. \& Lazkov) Lazkov, and B. sect. Macrostachya (R. Bhattacharjee) Krestovsk.), has not received statistical support by any so far published molecular phylogenies [e.g., 52, 53]. Betonica alopecuros L., however, receives support as sister to the remaining species in these studies. The distinctness of B. alopecuros is also supported by morphology: yellow corollas with bifid upper lip and annulate corolla tubes [172, 177]. A more comprehensive study of this genus is needed.

\section{Tribe Galeopseae (Dumort.) Vis.}

In the present study, we propose resurrection of the tribe Galeopseae to accommodate the phenetically and genetically isolated genus Galeopsis in Lamioideae. Dumortier [167] established subtribe Galeopsinae (as "Galeopsideae") within the Stachydeae and included the two genera, Galeopsis and Lamium L. Later, Visiani [178] elevated subtribe Galeopsinae to the rank of tribe 
(as "Galeopsideae" [98]) but included only Galeopsis. Galeopsis represents a morphologically highly distinct genus within subfamily Lamioideae, characterized by erect annual herbs with two conical protuberances near the base of the anterior lip of the corolla and anthers dehiscing by two valves, of which the upper is fimbriate [ 1 , 179].

Galeopsis comprises 10 currently accepted species, two subspecies, and six documented hybrids [165]. The genus is distributed in temperate Eurasia with a center of species richness in Europe [180]. Strong support for the monophyly of Galeopsis was obtained in two recent molecular phylogenetic studies of Lamioideae that included three [52] and eight [53] species of Galeopsis, respectively.

Phylogenetically, Galeopsis holds a rather isolated, yet uncertain, position and has remained unclassified at the tribal level [52, 53, 69]. In both Scheen et al. [52] and Bendiksby et al. [53], Galeopsis was weakly supported as sister to Betonica, which in turn was sister to tribe Stachydeae, with even weaker support. Hence, a close relationship to Lamium and Lamiastrum Heist. ex Fabr., with which Galeopsis had been classified in most traditional classifications (e.g., subtribe Galeopsidinae Dumort.) based on the shared feature of a swollen corolla tube, was discarded. The sister relationship between Betonica and Galeopsis received some support from other sources of data. The two genera share the same base chromosome number [181] $(x=8)$, and flavonoid p-coumaroyl glucosides are present in both Betonica and G. subg. Galeopsis [182]. The placement of Galeopsis in the nuclear PPR phylogeny by Roy and Lindqvist [69], however, does not support a sister relationship to Betonica, and Galeopsis falls out largely unresolved in their Lamioideae phylogeny. Although our current plastomebased phylogeny corroborates a sister relationship between Galeopsis and Betonica, support values remain low (Fig. 1). Based upon this phylogenetic uncertainty, the lack of support from nuclear data, and a goal of achieving taxonomic stability, we resurrect the tribe Galeopseae to encompass the single genus Galeopsis.

Reichenbach [169] divided Galeopsis into two subgenera, G. subg. Galeopsis and G. subg. Ladanum Rchb. Subgenus Galeopsis, is readily distinguished from G. subg. Ladanum by the presence of rigid hairs and swollen stem nodes in the former. The division of the genera into two equally sized subgenera is supported by phytochemistry [182], crossing experiments [183], and molecular phylogenetics [53, 184]. Galeopsis subg. Galeopsis comprises the following five species: G. bifida Boenn., G. pubescens Besser., G. speciosa Mill., G. tetrahit L., and G. sulphurea Jord. According to molecular analyses by Bendiksby et al. [184], the latter appears to represent a valid species, distinct from G. speciosa, and represents the most likely maternal parent to G. tetrahit (G. pubescens being the paternal parent). Galeopsis subg. Ladanum comprises the following five species: $G$. ladanum L., G. nana Otsch., G. pyrenaica Bartl., G. reuteri Rchb. f., G. segetum Neck. Species within G. subg. Ladanum have proven indistinguishable in DNA phylogenetic analyses involving nuclear (NRPA2, 5S-NTS) and chloroplast (matK, psbA-trnH, rps16, trnL-trnF, and trnS-trnG) DNA regions (M. Bendiksby, unpubl.). Morphologically, however, they appear highly distinct, and AFLP data (genomic fingerprint) group accessions according to species [M. Bendiksby, unpubl.]. Hence, the species of G. subg. Ladanum have probably diverged recently and the multilocus data suffers from incomplete lineage sorting.

\section{Tribe Stachydeae Dumort.}

Cosmopolitan Stachydeae are the largest and taxonomically most challenging alliance of all recognized tribes in subfamily Lamioideae [29, 30, 52, 53, 69]. Stachydeae have previously been the subject of several molecular phylogenetic investigations [30, 37-39, 52, 53, 185]. Lindqvist and Albert [39] revealed that three genera endemic to Hawaiian (dry fruited Haplostachys (A. Gray) W.F. Hillebr., fleshy fruited Phyllostegia Benth., and Stenogyne Benth.) as well as the genera Prasium L., Phlomidoschema (Benth.) Vved., and Sideritis L. are nested within the large genus Stachys. Both Prasium with fleshy schizocarp and Phlomidoschema, which is characterized by a small corolla and branched hairs, are monotypic [1]. In contrast, Stachys comprises about 275 species and Sideritis comprises about 125 species [1]. This paraphyly of Stachys was corroborated by Scheen et al. [52] who showed that the Asian genera Chamaesphacos, Suzukia Kudô, and Thuspeinanta T. Durand also are embedded within Stachys and that the monotypic genus Melittis L. represents the sister to all other Stachydeae. In a later work, Bendiksby et al. [53] added Hypogomphia Bunge to the list of taxa nested within Stachys. Morphologically, the annuals Chamaesphacos, Hypogomphia, and Thuspeinanta are characterized by 1-3-flowered cymes and narrow nutlets, while Suzukia is recognized by a creeping habit and racemose inflorescences [1]. Thus, 12 genera and ca. 470 species are currently recognized in Stachydeae, but generic realignments are needed to reflect phylogenetic relationships. Scheen et al. [52] found no non-molecular synapomorphies for this diverse tribe, but listed the following characteristics as common among its members: calyx campanulate or weakly 2lipped, calyx lobes often spiny, calyx throat often hairy, corolla strongly 2-lipped, anterior pair of stamens bending outwards after pollination, and nutlets usually apically rounded. 
Besides some studies focusing on certain groups, such as Hawaiian [39, 185] and New World Stachys [30, 69], a comprehensive phylogenetic study of Stachydeae based on multiple loci analyses was performed by Salmaki et al. [29]. Analyses of nuclear ribosomal (nrITS) and plastid DNA data corroborated the monophyly of the tribe, with Melittis as sister to all remaining Stachydeae. Salmaki et al. [29] suggested the phylogenetic name "Eurystachys Y. Salmaki \& M. Bendiksby" for the clade including all genera attributed to Stachydeae except Melittis. Although the plastid DNA markers provided well-supported backbone resolution in the Eurystachys clade, the nrITS phylogenetic tree recovered several groups with relatively poorly supported and short branches [29]. Therefore, detailed conclusions on the phylogenetic relationships in the Eurystachys clade needed using additional nuclear markers.

Recently, phylogenetic relationships in the Eurystachys clade utilizing two additional nuclear ribosomal DNA sequences (nrETS and 5S-NTS) provided high resolution allowing recognition of 12 well-supported clades within the Eurystachys clade, which also were recovered in the previous phylogenetic analyses using plastid DNA sequences [186]. The 12 clades were formally named in the Eurystachys clade following a PhyloCode nomenclature [187] and provided the basis for a future rank-based classification of Stachydeae with two options: (1) splitting the Eurystachys clade into 12 individual genera, each based on a pre-existing genus name and redefined to encompass additional taxa, but without clear morphological apomorphies; or (2) lumping of all these formal clades into a broadly defined Stachys, including widely recognized and morphologically well-defined segregates such as Prasium and Sideritis [186]. Clearly, more studies using various sources of evidence are needed to clarify the taxonomic borders in this tribe. A micromorphological approach [153, 159-161, 188-192] at a global scale may provide a promising supplement to the more traditionally applied macro-morphological approaches.

\section{Tribe Paraphlomideae Bendiksby}

Paraphlomideae were established by Bendiksby et al. [53] to accommodate Matsumurella Makino (5 spp.), Ajugoides Makino (1 sp.), and Paraphlomis (Prain) Prain (ca. 25 spp.), together which have been found to form a distinct lineage within Lamioideae. Though the tribe has no clear synapomorphy, it can be distinguished from other tribes of Lamioideae by the following set of characters: herbs or subshrubs, indumentum of simple hairs, actinomorphic calyx, corolla (1/3) with hairy upper lip but scarcely bearded along the margin, included stamens, and an apically truncate ovary $[1,53,193]$. Most species of the tribe are restricted to East Asia (south
China and Japan), with some species of Paraphlomis extending to Southeast Asia [1, 193].

\section{Tribe Phlomideae Mathiesen}

Based on the most recent molecular phylogenetic study of Phlomideae [28], the tribe now consist of only two genera: Phlomis L. (ca. 50-90 spp.) and Phlomoides (ca. 150-170 spp.).

Phlomideae were established by Mathiesen in Scheen et al. [52], in which six genera were recognized in the tribe: Eremostachys, Lamiophlomis, Notochaete, Phlomis, Phlomoides, and Pseuderemostachys. Phlomideae are usually characterized by having calyx lobes abruptly narrowed to a narrow apex and expanded at the corolla margins that are bearded and densely pubescent outside and have branched hairs [52]. Mathiesen et al. [142] later reduced Pseuderemostachys, Lamiophlomis, and one species of Notochaete ( $N$. hamosa Benth.) to synonyms of Phlomoides. Combining multilocus molecular phylogenetic analyses and morphological evidence, Salmaki et al. [28] continued to show that Eremostachys, Notochaete, and Paraeremostachys Adylov, Kamelin \& Makhm should all be transferred to Phlomoides. Thus, the number of recognized genera in Phlomideae was reduced to two, i.e., Phlomis and Phlomoides. Species of Phlomis are shrubs or subshrubs with simple leaves, laterally compressed, flattened, sickle-shaped, but not fringed or incised upper corolla lips, and with nutlet pericarps possessing a sclerenchyma region (indistinct in a few species). In contrast, Phlomoides are herbaceous with simple or laciniate to pinnatisect leaves and with upper corolla lips that are arch-shaped, and always hairy or fringed-incised, but not laterally compressed or flattened, and have pericarps lacking a sclerenchyma region [194]. Phlomis have a mostly circum-Mediterranean distribution, while the centers of diversification of Phlomoides include Central Asia, the Iranian highlands, and China [28, 142, 195].

\section{Tribe Leonureae Dumort.}

Leonureae were recircumscribed by Scheen et al. [52] and Bendiksby et al. [53] based on phylogenetic and morphologic data. They are comprised of 80 species in six genera: Chaiturus Willd. (1 sp.), Lagochilus Bunge ex Benth. (45 spp.), Leonurus L. (24 spp.), Panzerina Soják (2 spp.), Loxocalyx Hemsl. (3 spp.), and Lagopsis (Bunge ex Benth.) Bunge (5 spp.). The tribe is distributed primarily in Central Asia. Phylogenetic studies have shown that Lagopsis and Leonurus are poly- or paraphyletic [53]. Possible morphological synapomorphies for the tribe are short stamens included in the corolla tube and more or less palmate venation and lobing of the leaves. The genus Loxocalyx lacks these characters but shares 
zygomorphic calyces with longer abaxial lobes with many Leonureae.

\section{Tribe Marrubieae Vis.}

Marrubieae, with about 91 species, consist mostly of non-aromatic herbs or subshrubs, with thyrsoid inflorescences, few- to many-flowered cymes, widely campanulate to rotate calyces often with secondary calyx lobes, zygomorphic and 2-lipped corollas, and included or shortly exserted stamens [1]. The tribe is distributed from Europe to west and central Asia as well as North and South Africa with the highest number of species in southern Europe and North Africa [33].

The taxonomy and generic delimitations within Marrubieae have been controversial [33, 52, 53, 196-198]. Marrubieae contained three genera, Ballota L., Marrubium L., and Moluccella L. based on Scheen et al. [52]. Later, Bendiksby et al. [53] showed that the two species of B. sect. Acanthoprasium Benth. (B. integrifolia Benth., $B$. frutescens (L.) Woods) form a clade separate from the remaining species of Ballota. Therefore, Bendiksby et al. [53] resurrected the genus Acanthoprasium as proposed (but not formalized) by Scheen et al. [52]. The monotypic Sulaimania Hedge \& Rech. f. was recovered as a member of the Moluccella clade and reduced to synonymy of Moluccella [53]. In a recent phylogenetic study of tribe Marrubieae using four plastid and one nuclear DNA locus (ITS), B. sect. Beringeria (Neck.) Benth. was raised to generic rank, as Pseudodictamnus Fabr. [33]. Therefore, the tribe now comprises five genera: Acanthoprasium (2 spp.), Ballota (3 spp.), Marrubium (ca. 50) spp., Moluccella (8 spp.), and Pseudodictamnus (28 spp.) [33].

Members of the genus Acanthoprasium are shrubby and woody, have long spiny bracteoles, and occur in Europe, while species of Pseudodictamnus are herbaceous, have leafy bracteoles, and are predominantly Mediterranean-African in distribution [33, 91]. Ballota as now circumscribed includes herbaceous species covered by simple trichomes and are distributed from Europe to West Asia (including also the Mediterranean) [33]. Marrubium was also recircumscribed recently to include B. deserti (de Noé) Jury, Rejdali \& A.J.K. Griffiths. There are around 50 species assigned to this genus, which are characterized by a bifid upper corolla lip and distributed from Macaronesia to temperate Eurasia.

\section{Tribe Leucadeae Scheen \& Ryding}

Leucadeae were established by Scheen et al. [52] and include ca. 134 species in six genera: Acrotome Benth. ex Endl. (8 spp.), Isoleucas O. Schwartz (2 spp.), Leonotis (Pers.) R. Br. (9 spp.), Leucas R. Br. (ca. 100 spp.), Otostegia Benth. (ca. 8 spp.), and Rydingia (4 spp.). These genera are distributed from Africa through the Indian subcontinent to Queensland, Australia [199]. With a few exceptions, members of Leucadeae have a calyx that is distinctly zygomorphic with secondary lobes and a bearded margin of the upper lip of the corolla [52]. The latter character is also found in the genus Phlomoides [52]. The monophyly of Leucadeae has been corroborated using low-copy nuclear data [69], although only a small but representative selection of species was included in this study.

One molecular phylogeny has included a wide representation of species from all six genera, but only cpDNA markers were analyzed [199]. The large genus Leucas, with more than 100 species occurring on dry or disturbed ground in tropical to southern Africa and tropical and subtropical parts of Asia [1], was shown to be paraphyletic with respect to Acrotome and Leonotis, Isoleucas, and Otostegia [199]. Only a few of the Asian species of Leucas were included, but they formed a clade separate from the remaining Leucas [199]. More data are needed, including low-copy nuclear markers, before taxonomic changes can be proposed.

The genus Otostegia, as traditionally circumscribed, was clearly polyphyletic [199]. To make Otostegia monophyletic, the genus Rydingia was described to accommodate four Asian species, one species was transferred to Isoleucas, and one species was transferred to Moluccella [141]. Since then, an additional four species of Otostegia have also been transferred to Moluccella [53] (see also the discussion on tribe Marrubieae). Thus, the recircumscribed Otostegia is reduced to ca. eight species, most of which are endemic to Africa [53], with O. fruticosa (Forssk.) Schweinf. ex Penz. extending to the Arabian Peninsula [200].

Molecular phylogenies have resolved Rydingia as sister to the rest of Leucadeae, with this relationship recovered based on cpDNA $[52,53]$ and low-copy nuclear DNA [69]. However, more data are still needed to resolve the generic boundaries of the paraphyletic genus Leucas in relation to Acrotome, Isoleucas, Leonotis, and Otostegia.

\section{Tribe Lamieae Coss. \& Germ.}

Lamieae are comprised of four genera: Lamium (including Wiedemannia Fisch. \& C.A. Mey and Lamiastrum; ca. 25 spp.), Eriophyton Benth. (including Alajja; ca. 8 spp.), Stachyopsis (4 spp.), and possibly Menitskia (Krestovsk.) Krestovsk. (1 sp.). These genera are widely distributed in the temperate and subtropical regions of Europe, Asia, and Northern Africa. Five East Asian species of Galeobdolon and Lamium chinense Benth. were transferred into the genus Matsumurella in tribe Paraphlomideae by Bendiksby et al. [53]. Possible morphological synapomorphies for the tribe are hairy anthers (except for Lamium galeobdolon L., L. flexuosum Ten., 
L. orvala L. and some other species in the genus Eriophyton) and nutlets subtruncate or truncate at apex.

Ryding [201] included Wiedemannia within Lamium, and Harley et al. [1] included Lamiastrum (syn. Galeobdolon) in Lamium. Scheen et al. [52] defined Lamieae to consist of a single genus Lamium (including Lamiastrum and Wiedemannia). Scheen et al. [52] and Bendiksby et al. [202] both found a clade comprised of Lamium, Lamiastrum, and Wiedemannia, but did not have sufficient sampling to assess monophyly of Lamium, e.g., if Lamiastrum and Wiedemannia were excluded. Subsequent studies, with more complete sampling of Lamium, found Lamiastrum to be nested within Lamium [203, 204].

Bendiksby et al. [53] also determined that two other genera, Eriophyton (including Alajja and three species of Lamium) and Stachyopsis, should be included in tribe Lamieae. Bendiksby et al. [143] found that Stachys tibetica Vatke (= Menitskia tibetica (Vatke) Krestovsk.) did not belong in Stachys (tribe Stachydeae), but was most closely related to Stachyopsis in Lamieae. Morphologically, however, S. tibetica has an intermediate position between Stachyopsis and Eriophyton. They expanded Eriophyton to include Stachyopsis and S. tibetica, in order to make Eriophyton monophyletic. Lazkov and Sennikov [176] stated that the genus Stachyopsis is similar to Eriophyton but differs in the habit, shape of leaves (oblong-ovate vs. broadly rhomboid-ovate), and shorter flower tube which is enclosed within the calyx; therefore, they suggested that the genus Stachyopsis should retain its generic status. At the same time, they resurrected Menitskia to accommodate S. tibetica as Menitskia tibetica. The genus Menitskia differs from Eriophyton and Stachyopsis by its narrower posterior corolla lip, stiffer bracteoles, and often deeply crenate to lobed leaves [143, 205].

\section{Taxonomic treatment}

\section{Colquhounieae}

C.L. Xiang, Bo Li \& R.G. Olmstead, trib. nov. Type: Colquhounia Wall.

Shrubs erect or ascending. Stems and branches terete, with simple and/or branched hairs. Leaves toothed, petiolate; inflorescence thyrsoid, pedunculate to subsessile; cymes 1-5-flowered. Calyx tubularcampanulate, 10-veined, 5-lobed, lobes often equal. Corolla strongly 2-lipped, 4-lobed (1/3), often purple, sometimes spotted; posterior lip moderately long, hooded with upcurved margins, anterior lip slightly subequally 3-lobed, corolla tube strongly dilated distally; stamens 4, not exserted from corolla, thecae \pm confluent; stigma lobes unequally 2-cleft. Nutlets narrowly obovoid-oblong, winged at apex.
Colquhounieae consist of one genus and approximately five species, occurring from Nepal, across north India to southwest and central China and Vietnam.

\section{Rotheceae}

C.L. Xiang, Bo Li \& R.G. Olmstead, trib. nov. Type: Rotheca Raf.

Shrubs, subshrubs, and perennial herbs. Leaves simple, opposite, or whorled with 3-4 leaves per node, often toothed. Flowers often in terminal and/or axillary cymes. Calyx actinomorphic, 5-lobed or truncate. Corolla \pm zygomorphic, expanding abruptly on lower side only; 5 lobes \pm unequal, anterior corolla lobe frequently much larger than the other four, limb in bud asymmetrical. Stamens 4, didynamous to subequal, long-exserted; anthers usually basifixed (occasionally approaching versatile). Ovary unlobed in flower but becoming imperfectly 4-lobed during fruit development. Style terminal, stigma lobes frequently unequal. Drupes (2-) 4-lobed, mesocarp \pm fleshy, endocarp separated into 4 stones or 2 pairs of stones.

The tribe contain four genera, Rotheca (60 spp.), Glossocarya (13 spp.), Discretitheca (1 sp.), and Karomia (9 spp.), and are distributed in tropical southern Asia to southern Africa, and Australia (Queensland).

\section{Betoniceae}

Bendiksby \& Salmaki, trib. nov. Type: Betonica L.

Perennial herbs. Leaves deeply crenate-dentate. Flowering stems unbranched, lateral to rootstock, verticillasters condensed (rarely remote), 16-20-flowered. Bracteoles scarious or herbaceous, apex spinescent, base broad and hardened. Flowers sessile, median lobe of lower corolla lip emarginate. Calyx sessile, \pm regular. Anther cells subparallel to parallel.

Betoniceae are monotypic comprising the genus Betonica with about 10 species distributed in western Eurasia.

\section{Conclusions}

This is the first study to use plastome data to estimate family-wide relationships within Lamiaceae. We demonstrate that increased taxon sampling in concert with phylogenomic analyses based on plastome sequence data provides superior support and resolution at both deep and shallow nodes relative to previous studies and offers new insights into phylogenetic relationships among and between tribes and subfamilies of Lamiaceae. The monophyly of all 12 subfamilies is corroborated, and we recognize a total of 22 tribes within Lamiaceae, three of which are newly established here (i.e. Colquhounieae, Rotheceae, and Betoniceae). This study provides a detailed summary of the taxonomic history, generic and species diversity, morphology, synapomorphies, and 
distribution for each tribe and subfamily, representing the most comprehensive overview of Lamiaceae since Harley et al. [1]. The classification presented herein is the most definitive tribal-level taxonomy of the mint family to date, and the robust phylogenetic backbone of Lamiaceae reconstructed here provides an extendable dataset for future studies on mint family classification, biogeography, character evolution, and diversification.

\section{Materials and methods}

\section{Taxon sampling}

In this study, plastomes of 50 taxa were newly sequenced and 61 taxa were reassembled from the sequence read archive (SRA) database; others were acquired from previous studies [66, 67, 206, 207] or downloaded from NCBI (https://www.ncbi.nlm.nih.gov; Additional file 8: Table S3). In total, the ingroup sampling included 170 taxa (175 accessions), 79 genera, and represented all 15 currently recognized tribes and all 12 subfamilies within Lamiaceae [19, 51]. Twenty-two species from five families of Lamiales (Mazaceae, Orobanchaceae, Phrymaceae, Paulowniaceae, and Wightiaceae) were selected as outgroups based on phylogenetic results of previous studies [18, 22, 208]. Voucher specimens of the newly sequenced taxa (Table 1) were deposited at the Herbarium of Kunming Institute of Botany, Chinese Academy of Sciences (KUN).

\section{DNA isolation and sequencing}

DNA was extracted from healthy and fresh leaves frozen in liquid nitrogen or dried in silica gel using the $C T A B$ protocol of Doyle and Doyle [209] and sheared into ca. 300 bp fragments using a Covaris M220 Focusedultrasonicator. Libraries for paired-end (PE) Illumina sequencing were constructed from fragmented genomic DNA following the standard protocol of manufacture (NEBNext ${ }^{\circ}$ Ultra I $^{\mathrm{Tm}}$ DNA Library Prep Kit for Illumina ${ }^{\circ}$ ) and sequenced from both ends of $150 \mathrm{bp}$ fragments on the Illumina HiSeq 2000 platform (Illumina, San Diego, CA, USA) at BGI Genomics (BGO-Shenzhen, China). Approximately $2-10 \mathrm{~GB}$ of raw data was generated with 150 bp paired-end read lengths.

\section{Plastome assembly and annotation}

Quality control of raw sequence reads was carried out using FastQC toolkit [210] (http://www.bioinformatics. babraham.ac.uk/projects/fastqc) with the parameter set as $\mathrm{Q} \geq 25$ to acquire high-quality clean reads. The de novo assembling of the plastome was implemented in the GetOrganelle pipeline [68], in which plastome reads were extracted from total genomic reads and then SPAdes v.3.10 [211] was used for assembly. For those plastomes we can acquire complete sequences, genome annotation was performed using Geneious v.11.0.3 [212], and the start and stop codons were manually adjusted by comparison with the plastome of Salvia miltiorrhiza Bunge [213] (HF586694). The online tRNAscan-SE web servers [214] were used to confirm the tRNA genes. Circular plastome maps were drawn using the OrganellarGenomeDRAW tool [215]. For 19 species, the plastomes were assembled from RNA-seq data and only contigs were obtained. Bowtie2 [216] was then used to map contigs to the reference sequences extracted from S. miltiorrhiza [213].

\section{Sequence alignment and dataset generation}

Since noncoding regions can be variable even among species and are often difficult to align across a family as large as Lamiaceae, only 79 protein-coding genes were used for phylogenetic analyses. Alignments of individual loci were performed using the MAFFT v.7.308 [217] plugin in Geneious v.11.0.3 [212] with G-INS-I algorithm, and the final alignments were manually adjusted in PhyDE v.0.9971 [218].

Since the plastome is uniparentally inherited in most angiosperms and generally does not undergo recombination, sequences of the 79 coding genes were concatenated in our study to generate a supermatrix of all coding regions (CR). Removal of problematic aligned regions may result in a better resolved phylogeny [219]; therefore, ambiguously aligned positions (e.g., characters of uncertain homology among taxa and single-taxon insertions; see [31, 46]) were removed manually in our analyses to construct the "Coding region manual" dataset (CRM, Additional file 3: Table S2).

Additional matrices for the 79 genes were constructed based on (1) the 1st and 2nd codon positions (CR12); (2) only the 3rd codon positions (CR3); and (3) the degenerated coded sequences (dePCS) generated using Degen v.1.4 (http://www.phylotools.com/). Thus, a total of five datasets (CR, CRM, CR12, CR3, dePCS) were used in subsequent analyses.

\section{Phylogenetic analyses}

Phylogenetic trees based on all datasets were built by two approaches including Bayesian inference (BI) analysis and maximum likelihood (ML) analysis. jModelTest v.2.1.4 [220] was used to determine the best-fit models for nucleotide sequences for BI analyses.

Bayesian analyses were executed using MrBayes v.3.2.2 [221]. Four iterations of 50,000,000 generations were run on four chains, sampling every 1000 generations on the Cyberinfrastructure for Phylogenetic Research Science (CIPRES) Gateway v.3.3 server [222] (http://www.phylo. org/). Default priors, unlinked parameter estimates, and best-fit models suggested by jModelTest v.2.1.4 [220] for each dataset were used for each iteration. Convergence of runs was accepted when the average standard 
deviation of split frequencies (ASDSF) dropped below 0.01 . Tracer v.1.6.0 [223] was used to inspect the convergence of model parameters and check whether the values of effective sample size (ESS) were $\geq 200$. A majority-rule consensus tree was created from the runs, after a $25 \%$ burn-in. All resulting trees with nodal support values were visualized and edited in FigTree v.1.4.2 [224].

ML analyses were performed using RAxML v.8.2.9 [225] as implemented in the XSEDE interface of CIPRES [222]. The GTRCAT model was used for analyses and bootstrapping; bootstrap iterations $(-\# \mid-\mathrm{N})$ were set to 1000, and other parameters used the CIPRES default settings.

We defined branches with posterior probabilities (PP) $<0.90$ and bootstrap values (BS) $<70 \%$ as weakly supported, $\mathrm{PP}=0.90-0.95$ and $\mathrm{BS}=70 \%-80 \%$ as moderately supported, and $\mathrm{PP} \geq 0.95$ and $\mathrm{BS} \geq 80 \%$ as strongly supported [107]. The alignments and ML tree are deposited at TreeBase with study \#S26639 (http://treebase.org/ treebase-web/phylows/study/TB2:S26639?x-accesscode $=$ bb02a 4 c5bc226f4604690ea0f21ccd $41 \&$ format $=$ html) [226].

\section{Supplementary Information}

The online version contains supplementary material available at https://doi. org/10.1186/s12915-020-00931-z.

Additional file 1: Figure S1. Gene maps of the complete chloroplast genomes newly sequenced in this study. Genes inside and outside of the circle are transcribed in the clockwise and counterclockwise directions, respectively. Genes belonging to different functional categories are colorcoded.

Additional file 2: Table S1. Features of newly sequenced plastomes. Additional file 3: Table S2. Excluded ambiguous sites for 79 genes of coding regions (dataset CRM).

Additional file 4: Figure S2. Phylograms inferred from $M L$ analysis of concatenated nucleotide sequences of 79 protein-coding genes (dataset CR). A, phylogram showing branch lengths, where tips names are absent follow the same order as shown in B. Scale bar represents the mean number of nucleotide substitutions per site. B, maximum likelihood bootstrap support values and Bayesian inference posterior probabilities are shown above and below the branches, respectively.

Additional file 5: Figure S3. Phylograms inferred from ML analysis of concatenated nucleotide sequences of the $3^{\text {rd }}$ codon positions (dataset CR3). A, phylogram showing branch lengths, where tip names are absent follow the same order as shown in B. Scale bar represents the mean number of nucleotide substitutions per site. B, maximum likelihood bootstrap support values and Bayesian inference posterior probabilities are shown above and below the branches, respectively.

Additional file 6: Figure S4. Phylograms inferred from ML analysis of concatenated nucleotide sequences of the $1^{\text {st }}$ and $2^{\text {nd }}$ codon positions (dataset CR12). A, phylogram showing branch lengths, where tips names are absent follow the same order as shown in B. Scale bar represents the mean number of nucleotide substitutions per site. B, maximum likelihood bootstrap support values and Bayesian inference posterior probabilities are shown above and below the branches, respectively.

Additional file 7: Figure S5. Phylograms inferred from ML analysis of concatenated nucleotide sequences of the degeneracy nucleotide sequence (dataset dePCS). A, phylogram showing branch lengths, where tip names are absent follow the same order as shown in B. Scale bar represents the mean number of nucleotide substitutions per site. B, maximum likelihood bootstrap support values are shown above the branches.

Additional file 8: Table S3. List of taxa sampled with information related to taxonomy, GenBank accession numbers, references, and vouchers. Herbarium acronyms follow Index Herbariorum [227].

\section{Acknowledgements}

The authors thank Dr. Miao Sun, Dr. Qing-Qing Zhan, Dr. Zhuo Zhou, Dr. Ren-Bin Zhu, Paul Carmen (Australian National Botanic Gardens), and Dr. Jian Huang for their assistance in sample collection.

\section{Authors' contributions}

$C L X, B L, F Z, Y P C, H P$, and $R G O$ conceived this research. FZ, YPC, BTD, TCW, $F C, B L$, and CLX collected materials. FZ performed the experiments. FZ, YPC, and $\mathrm{XCL}$ analyzed the data. All the authors wrote the manuscript. All authors read and approved the final version of manuscript.

\section{Funding}

This study was in part supported by Yunnan Fundamental Research Projects (Grant No. 2019FI009) and "Ten Thousand Talents Program of Yunnan" (Grant No. YNWR-QNBJ-2018-279) awarded to CLX, the CAS "Light of West China" program to CLX and YPC, the Australian Biological Resources Study National Taxonomy Research Grant Program (Grant No. RG19-17) awarded to TCW, CLX, and BL, NSF DEB-1655611 awarded to BTD, and the Postdoctoral Research Program (TUBITAK-BIDEB 2219) awarded to FC.

\section{Availability of data and materials}

All the newly sequenced and annotated plastomes in the present study were submitted to the National Center for Biotechnology Information (NCBI) database with accession numbers MT473738-MT473786 (Table 1). Other plastomes analyzed were acquired from previous studies $[66,67,206,207]$ or downloaded from NCBI (https://www.ncbi.nlm.nih.gov;

Additional file 8; Table S3). The alignments and ML tree are deposited at TreeBase with study \#S26639 (http://treebase.org/treebase-web/phylows/ study/TB2:S26639?x-access-code=bb02a4c5bc226f4604690ea0f21 ccd41 \&format=html) [226].

Ethics approval and consent to participate Not applicable.

\section{Consent for publication}

Not applicable.

\section{Competing interests}

The authors declare that they have no competing interests.

\section{Author details}

${ }^{1}$ CAS Key Laboratory for Plant Diversity and Biogeography of East Asia, Kunming Institute of Botany, Chinese Academy of Sciences, Kunming 650201, China. ${ }^{2}$ Center of Excellence in Phylogeny of Living Organisms, Department of Plant Science, College of Science, University of Tehran, P.O. Box 14155-6455, Tehran, Iran. ${ }^{3}$ Department of Biology, University of Nebraska at Kearney, Kearney, NE 68849, USA. ${ }^{4}$ National Herbarium of New South Wales, Australian Institute of Botanical Science, Royal Botanic Gardens \& Domain Trust, Sydney, Australia. ${ }^{5}$ Museum of Archaeology, University of Stavanger, NO-4036 Stavanger, Norway. ${ }^{6}$ Department of Biology, Faculty of Arts and Sciences, Kırıkkale University, Kırıkkale, Turkey. ${ }^{7}$ Department of Botany, University of Wisconsin-Madison, Madison, WI 53706, USA. ${ }^{8}$ Department of Botany, Natural History Museum Vienna, Burgring 7, 1010 Wien, Austria. ${ }^{9}$ NTNU University Museum, Norwegian University of Science and Technology, 7491 Trondheim, Norway. ${ }^{10}$ Natural History Museum, University of Oslo, Oslo, Norway. ${ }^{11}$ State Key Laboratory of Systematic \& Evolutionary Botany, Institute of Botany, Chinense Academy of Sciences, Xiangshan, Beijing 100093, China. ${ }^{12}$ Research Centre of Ecological Sciences, College of Agronomy, Jiangxi Agricultural University, Nanchang 330045, China. ${ }^{13}$ Department of Biology, University of Washington, Seattle, WA, USA. 
Received: 21 July 2020 Accepted: 19 November 2020 Published online: 08 January 2021

\section{References}

1. Harley RM, Atkins S, Budantsev AL, Cantino PD, Conn BJ, Grayer R, et al. Labiatae. In: Kadereit JW, editor. The families and genera of vascular plants, vol. 7. Berlin: Springer Verlag; 2004. p. 167-275.

2. Olmstead RG. A synoptical classification of the Lamiales, version 2.6.2. 2016. http://depts.washington.edu/phylo/Classification.pdf. Accessed 25 Feb 2020. (last updated 12 April, 2016).

3. APG IV. An update of the Angiosperm Phylogeny Group classification for the orders and families of flowering plants: APG IV. Bot J Linn Soc. 2016;181: $1-20$.

4. Bentham G. Verbenaceae and Labiatae. In: Bentham G, Hooker JD, editors. Genera plantarum. London: Reeve; 1876. p. 1131-223.

5. Briquet J. Verbenaceae, Labiatae. In: HGA E, KAE P, editors. Die Natürlichen Pflanzenfamilien. Berlin: Engelmann, W; 1897. p. 132-375.

6. Erdtman G. Pollen morphology and plant taxonomy. IV. Labiatae, Verbenaceae and Avicenniaceae. Svensk Bot Tidskr. 1945;39:277-85.

7. Wunderlich R. Ein Vorschlag zu einer natürlichen Gliederung der Labiaten auf Grund der Pollenkörner, der Samenentwicklung und des reifen Samens. Oester Bot Zeit. 1967;114:383-483.

8. Cantino PD, Sanders RW. Subfamilial classification of Labiatae. Syst Bot 1986;11:163-85.

9. Cantino PD. Evidence for a polyphyletic origin of the Labiatae. Ann Mo Bot Gard. 1992;79:361-79.

10. Cantino PD. Toward a phylogenetic classification of the Labiatae. In: Harley RM, Reynolds T, editors. Advances in Labiatae Science. London: Royal Botanic Gardens, Kew; 1992. p. 27-37.

11. Cantino PD, Harley RM, Wagstaff SJ. Genera of Labiatae: status and classification. In: Harley R, Reynolds T, editors. Advances in Labiatae science. London: Royal Botanic Gardens, Kew; 1992. p. 511-22.

12. Junell S. Zur Gynäzeummorphologie und Systematik der Verbenaceen und Labiaten, nebst Bemerungen über ihre Samenentwicklung. Symb Bot Upsal. 1934;4:1-129.

13. Kadereit JW. Lamiales: introduction and conspectus. In: Kadereit JW, editor The Families and Genera of Vascular Plants, Vol. 7. Berlin: Springer Verlag; 2004. p. 1-8.

14. Wink M, Kaufmann M. Phylogenetic relationships between some members of the subfamily Lamioideae (Family Labiatae) inferred from nucleotide suquences of the rbcL gene. Bot Acta. 1996;109:139-48.

15. Wagstaff SJ, Olmstead RG. Phylogeny of Labiatae and Verbenaceae inferred from rbcL sequences. Syst Bot. 1997;22:165-79.

16. Wagstaff SJ, Hickerson L, Spangler R, Reeves PA, Olmstead RG. Phylogeny in Labiatae s.l., inferred from cpDNA sequences. Plant Syst Evol. 1998;209:26574

17. Schäferhoff B, Fleischmann A, Fischer E, Albach DC, Borsch T, Heubl G, et al. Towards resolving Lamiales relationships: insights from rapidly evolving chloroplast sequences. BMC Evol Biol. 2010;10:352.

18. Refulio-Rodriguez NF, Olmstead RG. Phylogeny of Lamiidae. Am J Bot. 2014; 101:287-99.

19. Li B, Cantino PD, Olmstead RG, Bramley GL, Xiang C-L, Ma Z-H, et al. A large-scale chloroplast phylogeny of the Lamiaceae sheds new light on its subfamilial classification. Sci Rep. 2016;6:34343.

20. Mint Evolutionary Genomics Consortium. Phylogenomic mining of the mints reveals multiple mechanisms contributing to the evolution of chemical diversity in Lamiaceae. Mol Plant. 2018;11:1084-96.

21. Soltis DE, Smith SA, Cellinese N, Wurdack KJ, Tank DC, Brockington SF, et al. Angiosperm phylogeny: 17 genes, 640 taxa. Am J Bot. 2011;98:704-30.

22. Liu B, Tan Y-H, Liu S, Olmstead R, Ming D-Z, Chen Z-D, et al. Phylogenetic relationships of Cyrtandromoea and Wightia revisited: a new tribe in Phrymaceae and a new family in Lamiales. J Syst Evol. 2020;58:1-17.

23. Paton AJ, Springate D, Suddee S, Otieno D, Grayer RJ, Harley MM, et al. Phylogeny and evolution of basils and allies (Ocimeae, Labiatae) based on three plastid DNA regions. Mol Phylogenet Evol. 2004;31:277-99.

24. Conn BJ, Streiber N, Brown EA, Heywood MJ, Olmstead RG. Infrageneric phylogeny of Chloantheae (Lamiaceae) based on chloroplast ndhF and nuclear ITS sequence data. Aust Syst Bot. 2009:22:243-56.

25. Bräuchler C, Meimberg H, Heubl G. Molecular phylogeny of Menthinae (Lamiaceae, Nepetoideae, Mentheae) - taxonomy, biogeography and conflicts. Mol Phylogenet Evol. 2010;55:501-23.
26. Pastore JFB, Harley RM, Forest F, Paton AJ, Van den Berg C. Phylogeny of the subtribe Hyptidinae (Lamiaceae tribe Ocimeae) as inferred from nuclear and plastid DNA. Taxon. 2011;62:1217-329.

27. Drew BT, Sytsma KJ. Phylogenetics, biogeography, and staminal evolution in the tribe Mentheae (Lamiaceae). Am J Bot. 2012;99:933-53.

28. Salmaki $Y$, Zarre $S$, Ryding $O$, Lindqvist $C$, Scheunert $A$, Bräuchler $C$, et al. Phylogeny of the tribe Phlomideae (Lamioideae: Lamiaceae) with special focus on Eremostachys and Phlomoides: new insights from nuclear and chloroplast sequences. Taxon. 2012;65:161-79.

29. Salmaki Y, Zarre S, Ryding O, Lindqvist C, Bräuchler C, Heubl G, et al. Molecular phylogeny of tribe Stachydeae (Lamiaceae subfamily Lamioideae) Mol Phylogenet Evol. 2013;69:535-51.

30. Roy T, Chang T-H, Lan T, Lindqvist C. Phylogeny and biogeography of New World Stachydeae (Lamiaceae) with emphasis on the origin and diversification of Hawaiian and South American taxa. Mol Phylogenet Evol. 2013;69:218-38.

31. Chen Y-P, Drew BT, Li B, Soltis DE, Soltis PS, Xiang C-L. Resolving the phylogenetic position of Ombrocharis (Lamiaceae), with reference to the molecular phylogeny of tribe Elsholtzieae. Taxon. 2016;65:123-36.

32. Paton AJ, Mwanyambo M, Culham A. Phylogenetic study of Plectranthus, Coleus and allies (Lamiaceae): taxonomy, distribution and medicinal use. Bot J Linn Soc. 2018;188:355-76.

33. Siadati S, Salmaki Y, Mehrvarz SS, Heubl G, Weigned M. Untangling the generic boundaries in tribe Marrubieae (Lamiaceae: Lamioideae) using nuclear and plastid DNA sequences. Taxon. 2018:67:770-83.

34. Steane DA, Scotland RW, Mabberley DJ, Wagstaff SJ, Reeves PA, Olmstead RG. Phylogenetic relationships of Clerodendrum s.l. (Lamiaceae) inferred from chloroplast DNA. Syst Bot. 1997;22:229-43.

35. Steane DA, Scotland RW, Mabberley DJ, Olmstead RG. Molecular systematics of Clerodendrum (Lamiaceae): ITS sequences and total evidence. Am J Bot 1999;86:98-107.

36. Steane DA, De Kok RPJ, Olmstead RG. Phylogenetic relationships between Clerodendrum (Lamiaceae) and other Ajugoid genera inferred from nuclear and chloroplast DNA sequences data. Mol Phylogenet Evol. 2004;32:39-45.

37. Barber JC, Francisco-Ortega J, Santos-Guerra A, Turner KG, Jansen RK. Origin of Macaronesian Sideritis L. (Lamioideae: Lamiaceae) inferred from nuclear and chloroplast sequence datasets. Mol Phylogent Evol. 2002;23:293-306.

38. Barber JC, Finch CC, Francisco-Ortega J, Santos-Guerra A, Jansen RK. Hybridization in Macaronesian Sideritis (Lamiaceae): Evidence from incongruence of multiple independent nuclear and chloroplast sequence datasets. Taxon. 2007:56:74-88

39. Lindqvist C, Albert VA. Origin of the Hawaiian endemic mints within the North American Stachys (Lamiaceae). Am J Bot. 2002;89:1709-24.

40. Walker JB, Sytsma KJ, Treutlein J, Wink M. Salvia (Lamiaceae) is not monophyletic: implications for the systematics, radiation, and ecological specializations of Salvia and tribe Mentheae. Am J Bot. 2004;91:1115-25.

41. Walker JB, Drew BT, Sytsma KJ. Unravelling species relationships and diversification within the iconic California Floristic Province sages (Salvia subgenus Audibertia, Lamiaceae). Syst Bot. 2015;40:826-44.

42. Bramley GLC, Forest F, De Kok RPJ. Troublesome tropical mints: Reexamining generic limits of Vitex and relations (Lamiaceae) in South East Asia. Taxon. 2009;58:500-10.

43. Xiang C-L, Zhang Q, Scheen A-C, Cantino PD, Funamoto T, Peng H. Molecular phylogenetics of Chelonopsis (Lamiaceae: Gomphostemmateae) as inferred from nuclear and plastid DNA and morphology. Taxon. 2013;62:375-86.

44. Chen Y-P, Li B, Olmstead RG, Cantino PD, Xiang C-L, Liu E-D. Phylogenetic placement of the enigmatic genus Holocheila (Lamiaceae) inferred from plastid DNA sequences. Taxon. 2014;63:355-66.

45. Drew BT, Cacho NI, Sytsma KJ. The transfer of two rare monotypic genera, Neoeplingia and Chaunostoma, to Lepechinia (Lamiaceae), and notes on their conservation. Taxon. 2014:63:831-42.

46. Drew BT, González-Gallegos JG, Xiang C-L, Kriebel R, Drummond CP, Walker $J B$, et al. Salvia united: The greatest good for the greatest number. Taxon. 2017:66:133-45.

47. González-Gallegos JG, Drew B, Cuevas-Guzmán R. Novelties on the distribution of Lepechinia flammea (Lamiaceae), rediscovery of L. glomerata in Jalisco, Mexico, and their phylogenetic position within Lepechinia. Bot Sci. 2015;93:1-14.

48. Salmaki Y, Kattari S, Heubl G, Bräuchler C. Phylogeny of non-monophyletic Teucrium (Lamiaceae: Ajugoideae): implications for character evolution and taxonomy. Taxon. 2016;65:802-22. 
49. Will M, Claßen-Bockhoff R. Time to split Salvia s.l. (Lamiaceae)-New insights from Old World Salvia phylogeny. Mol Phylogenet Evol. 2017;109:33-58.

50. Hu G-X, Takano A, Drew BT, Liu E-D, Soltis DE, Soltis PS, et al. Phylogeny and staminal evolution of Salvia (Lamiaceae, Nepetoideae) in East Asia. Ann Bot. 2018;122:649-68

51. Li B, Olmstead RG. Two new subfamilies in Lamiaceae. Phytotaxa. 2017;313: 222-6.

52. Scheen A-C, Bendiksby M, Ryding O, Mathiesen C, Albert VA, Lindqvist C. Molecular phylogenetics, character evolution and suprageneric classification of Lamioideae (Lamiaceae). Ann Mo Bot Gard. 2010:97:191-219.

53. Bendiksby M, Thorbek L, Scheen A-C, Lindqvist C, Ryding O. An updated phylogeny and classification of Lamiaceae subfamily Lamioideae. Taxon. 2011;60:471-84

54. Xiang C-L, Zhao F, Cantino PD, Drew BT, Li B, Liu E-D, et al. Molecular systematics of Caryopteris (Lamiaceae) and its allies with reference to the molecular phylogeny of subfamily Ajugoideae. Taxon. 2018;67:376-94.

55. Moore MJ, Bell CD, Soltis PS, Soltis DE. Using plastid genome-scale data to resolve enigmatic relationships among basal angiosperms. Proc Natl Acad Sci U S A. 2007;104:19363-8.

56. Olmstead RG, Bedoya AM. Whole genomes: the holy grail. A commentary on: 'molecular phylogenomics of the tribe Shoreeae (Dipterocarpaceae) using whole plastidgenomes'. Ann Bot. 2019;123:iv-V.

57. Lin C-P, Huang J-P, Wu C-S, Hsu C-Y, Chaw S-M. Comparative chloroplast genomics reveals the evolution of Pinaceae genera and subfamilies. Genome Biol Evol. 2010;2:504-17.

58. Moore MJ, Soltis PS, Bell CD, Burleigh JG, Soltis DE. Phylogenetic analysis of 83 plastid genes further resolves the early diversification of eudicots. Proc Natl Acad Sci U S A. 2010;107:4623-8.

59. Xi Z, Ruhfel BR, Schaefer $H$, Amorim AM, Sugumaran M, Wurdack K, et al. Phylogenomics and a posteriori data partitioning resolve the Cretaceous angiosperm radiation Malpighiales. Proc Natl Acad Sci U S A. 2012;109:17519-24.

60. Stull GW, De Stefano RD, Soltis DE, Soltis PS. Resolving basal lamiid phylogeny and the circumscription of Icacinaceae with a plastome-scale data set. Am J Bot. 2015;102:1794-813.

61. Zhang S-D, Jin J-J, Chen S-Y, Chase MW, Soltis DE, Li H-T, et al. Diversification of Rosaceae since the late Cretaceous based on plastid phylogenomics. New Phytol. 2017;214:1355-67.

62. Zhang $\mathrm{R}$, Wang $\mathrm{Y}-\mathrm{H}$, Jin J-J, Stull GW, Bruneau A, Cardoso D, et al. Exploration of plastid phylogenomic conflict yields new insights into the deep relationships of Leguminosae. Syst Biol. 2020;69:613-22.

63. Yu X-Q, Gao L-M, Soltis DE, Soltis PS, Yang J-B, Fang L, et al. Insights into the historical assembly of East Asian subtropical evergreen broadleaved forests revealed by the temporal history of the tea family. New Phytol. 2017;215:1235-48.

64. Yang X-Y, Wang Z-F, Luo W-C, Guo X-Y, Zhang C-H, Liu J-Q, et al. Plastomes of Betulaceae and phylogenetic implication. J Syst Evol. 2019;57:508-18.

65. Xiang C-L, Dong H-J, Landrein S, Zhao F, Yu W-B, Soltis DE, et al. Revisiting the phylogeny of Dipsacales: new insights from phylogenomic analyses of complete plastomic sequences. J Syst Evol. 2020;58:103-17.

66. Zhao F, Li B, Drew BT, Chen Y-P, Wang Q, Yu W-B, et al. Leveraging plastomes of comparative analysis and phylogenomic inference within Scutellarioideae (Lamiaceae). Plos One. 2020;15:e0232602.

67. Zhao F, Drew BT, Chen Y-P, Hu G-X, Li B, Xiang C-L. The chloroplast genome of Salvia species: genomic characterization and phylogenetic analysis. Int J Plant Sci. 2020;181:812-30.

68. Jin J-J, Yu W-B, Yang J-B, Song Y, de Pamphilis CW, Yi T-S, et al. GetOrganelle: a fast and versatile toolkit for accurate de novo assembly of organelle genomes. Genome Biol. 2020;21:241.

69. Roy T, Lindqvist C. New insights into evolutionary relationships within the subfamily Lamioideae (Lamiaceae) based on pentatricopeptide repeat (PPR) nuclear DNA sequences. Am J Bot. 2015;102:1721-35.

70. Guignard ML. Recherches sur la développement de la graine et en particulier du tégument seminal: Labiées. J Bot. 1893;7:241-50.

71. Olmstead RG, Reeves PA, Lepschi BJ. Confirmation of a monophyletic Chloanthoideae (Lamiaceae) comprising tribes Chloantheae and Prostanthereae. Lamiales Newsletter. 1998;6:7-10.

72. Godden GT, Kinser TJ, Soltis PS, Soltis DE. Phylotranscriptomic analyses reveal asymmetrical gene duplication dynamics and signatures of ancient polyploidy in mints. Genome Biol Evol. 2019;11:3393-408.

73. Conn BJ, Henwood MJ, Streiber N. Synopsis of the tribe Chloantheae and new nomenclatural combinations in Pityrodia s.lat. (Lamiaceae). Aust Syst Bot. 2011;24:1-9.
74. Munir AA. A taxonomic revision of Chloanthaceae trib. Physopsideae Brunonia. 1978;1:407-692.

75. Brown R. Prodromus Florae Novae Hollandiae. London: J. Johnson \& Co; 1810.

76. Reichenbach HGL. Conspectus regni vegetabilis per gradus naturales evoluti. Leipzig: Carolum Cnobloch; 1828.

77. Von Mueller FJH. Nova genera et species aliquot rariores in plagis Australiae. Hooker's J Bot Kew Gard Misc. 1857:9:14-24.

78. Hutchinson J. The Families of Flowering Plants. 2nd ed. London: Oxford University Press; 1959.

79. Munir AA. A taxonomic revision of the genus Hemiphora (Chloanthaceae). J Adel Bo Gard. 1978;1:161-6.

80. Eichler H. Supplement to J.M. Black's Flora of South Australia. 2nd edition. Adelaide: Govt. Printer; 1965.

81. Munir AA. A taxonomic revision of the genus Chloanthes (Chloanthaceae). J Adel Bo Gard. 1977;1:83-106.

82. Munir AA. A taxonomic revision of the genus Cyanostegia (Chloanthaceae). Brunonia. 1978;1:45-67.

83. Munir AA. A taxonomic revision of the genus Pityrodia (Chloanthaceae). J Adel Bo Gard. 1979;2:1-138.

84. Blackall WE, Grieve BJ. How to know Western Australian wildflowers: a key to the flora of the temperate regions of Western Australia. Nedlands: University of Western Australia Press; 1965.

85. Cronquist A. The evolution and classification of flowering plants. Aylesbury: Hazel Watson \& Viney; 1968.

86. Wilson TC, Radunz EA, Chen S, Conn BJ, Henwood MJ. A new genus and species for Chloantheae (Lamiaceae). Aust Syst Bot. 2020; In press.

87. Guerin GR. Evidence for polyphyly in Hemigenia and Microcorys (Lamiaceae: Westringieae). Aust Syst Bot. 2008;21:313-25.

88. Huck RB. Overview of pollination biology in the Lamiaceae. In: Harley RM, Reynolds T, editors. Advances in Labiatae Science. London: Royal Botanic Gardens, Kew; 1992. p. 167-81.

89. Wilson TC, Conn BJ, Henwood MJ. Great expectations: correlations between pollinator assemblages and floral characters in Lamiaceae. Int J Plant Sci. 2017;178:170-87.

90. Wilson TC, Conn BJ, Henwood MJ. Molecular phylogeny and systematics of Prostanthera (Lamiaceae). Aust Syst Bot. 2012;25:341-52.

91. Bentham G. Labiatarum genera et species. London: J. Ridgeway \& Sons; 1834.

92. Guerin GR. Nutlet morphology in Hemigenia R.Br. and Microcorys R.Br. (Lamiaceae). Plant Syst Evol. 2005;254:49-68.

93. Hedge IC. Labiatae. In: Ali SI, Nasir YJ, editors. Flora of Pakistan, vol. 192. Karachi: University of Karachi; 1990. p. 310.

94. Kaufmann M, Wink M. Molecular systematics of the Nepetoideae (Lamiaceae): Phylogenetic implications from rbcL gene sequences. Z Naturforsch C. 1994:49:635-45.

95. Wagstaff SJ, Olmstead RG, Cantino PD. Parsimony analysis of cpDNA restriction site variation in subfamily Nepetoideae (Labiatae). Am J Bot. 1995;82:886-92.

96. Martin AC. The comparative internal morphology of seeds. Ame Mid Natur. 1946;36:513-660.

97. Ryding O. The distribution and evolution of myxocarpy in Lamiaceae. In: Harley RM, Reynolds T, editors. Advances in Labiatae Science. London: Royal Botanic Gardens, Kew; 1992. p. 85-96.

98. Li P, Qi Z-C, Liu L-X, Ohi-Toma T, Lee J, Hsieh TH, et al. Molecular phylogenetics and biogeography of the mint tribe Elsholtzieae (Nepetoideae, Lamiaceae), with an emphasis on its diversification in East Asia. Sci Rep. 2017;7:2057.

99. Sanders RW, Cantino PD. Nomenclature of the subdivisions of the Lamiaceae. Taxon. 1984;33:64-72.

100. Funamoto T, Xiang C-L, Ogawa M, Peng H. A comparative study of chromosome characters in four species of Elsholtzia Will. (Lamiaceae) in Japan and China. Chromosome Bot. 2012;7:119-23.

101. Mayta-Anco LF, Molinari-Novoa EA, Raju AJS. A new genus within the Elsholtziae (Lamiaceae) from southeast Asia. Weberbauerella. 2016;1:1-7.

102. Paton AJ, Ryding O. Hanceola, Siphocranion and Isodon and their position in the Ocimeae (Labiatae). Kew Bull. 1998;53:723-31.

103. Harley RM, Pastore JFB. A generic revision and new combinations in the Hyptidinae (Lamiaceae), based on molecular and morphological evidence. Phytotaxa. 2012:58:1-55.

104. Paton AJ, Mwanyambot M, Govaerts RHA, Smitha K, Suddee S, Phillipson PB, et al. Nomenclatural changes in Coleus and Plectranthus (Lamiaceae): a tale of more than two genera. PhytoKeys. 2019;129:1-158. 
105. Harley RM, Paton AJ, Ryding O. New synonym and taxonomic changes in Laibatae. Kew Bull. 2003;58:485-9.

106. Zhong J-S, Li J, Li L, Conran JG, Li H-W. Phylogeny of Isodon (Schrad. ex Benth.) Spach (Lamiaceae) and related genera inferred from nuclear ribosomal ITS, trnL-trnF region, and rps 16 intron sequences and morphology. Syst Bot. 2010;35:207-19.

107. Chen Y-P, Zhu X-X, Zhao F, Feng H-Z, Paton A, Xiang C-L. Molecular and morphological evidence for a new species of Siphocranion (Lamiaceae) from the Sino-Vietnamese border. Phytotaxa. 2019;425:1-18.

108. Walker JB, Sytsma KJ. Staminal evolution in the genus Salvia (Lamiaceae): molecular phylogenetic evidence for multiple origins of the staminal lever. Ann Bot. 2007;100:375-91.

109. Drew BT, Sytsma KJ. Testing the monophyly and placement of Lepechinia in the tribe Mentheae (Lamiaceae). Syst Bot. 2011;36:1038-49.

110. Drew BT. Phylogenetics and biogeography of Lepechinia (Lamiaceae), and evolutionary studies within the Mentheae Tribe. Ph.D. dissertation. Madison: University of Wisconsin; 2011.

111. Rouy G. Compectus de la Flore de France. Paris: Rue de tournon; 1927.

112. Moon HK, Vinckier S, Smets E, Huysmans S. Palynological evolutionary trends within the tribe Mentheae with special emphasis on subtribe Menthinae (Nepetoideae: Lamiaceae). Plant Syst Evol. 2008;275:93-108

113. Li J-C, Zhang J-W, Zhang D-G, Deng T, Volis S, Sun H, et al. Phylogenetic position of the Chinese endemic genus Heterolamium: a close relative of subtribe Nepetinae (Lamiaceae). J Jap Bot. 2017;92:12-9.

114. Takhtajan A. Flowering Plants. Netherlands: Springer; 2009.

115. Thorne RF. Classification and geography of the flowering plants. Bot Rev. 1992;58:225-348.

116. Cronquist A. The evolution and classification of flowering plants. New York: Columbia University Press; 1988.

117. Reveal JL. An outline of a classification scheme for extant flowering plants. Phytoneuron. 2012;37:1-211.

118. Barrabé L, Karnadi-Abdelkader G, Ounémoa J, De Kok RPJ, Robert N, Gâteblé G. Recircumscription of Oxera (Lamiaceae: Ajugoideae) to include Faradaya based on molecular and anatomical data. Bot J Linn Soc. 2015;179:693-791.

119. Barrabé L, Lavergne S, Karnadi-Abdelkader G, Drew BT, Birnbaum P, Gâteblé G. Changing ecological opportunities facilitated the explosive diversification of New Caledonian Oxera (Lamiaceae). Syst Biol. 2018;68:460-81.

120. Thorne RF. The calssificaiton and geography of the flowering plants: Dicotyledons of the class Angiospermae. Bot Rev. 2000;66:441-647.

121. Abu-Asab MS, Cantino PD. Phylogenetic implications of pollen morphology in Tribe Ajugeae (Labiatae). Syst Bot. 1993;18:100-22.

122. Dumortier BC. Analyse des Familles des Plantes. Tournay: J. Casterman; 1829

123. Steane DA, Mabberley DJ. Rotheca (Lamiaceae) revived. Novon. 1998;8:204-6.

124. Yuan Y-W, Mabberley DJ, Steane DA, Olmstead RG. Further disintegration and redefinition of Clerodendrum (Lamiaceae): implications for the understanding of the evolution of an intriguing breeding strategy. Taxon. 2010;59:125-33.

125. Charles-Dominique T, Davies TJ, Hempson GP, Bezeng BZ, Daru BH, Kabongo RM, et al. Spiny plants, mammal browsers, and the origin of African savannas. Proc. Natl Acad Sci U S A. 2016;113:E5572-9.

126. Huang MJ, Crawford DJ, Freudenstein JV, Cantino PD. Systematics of Trichostema (Lamiaceae): evidence from ITS, ndhF, and morphology. Syst Bot. 2008;33:437-46.

127. Chen S-L, Guo R-L. Caryopteris. In: Chen S-L, Pei J, editors. Flora Reipublicae Popularis Sinicae, vol. 65(1). Beijing: Science Press; 1982. p. 194-208.

128. Rimpler H, Winterhalter C, Falk U. Cladistic analysis of the subfamily Caryopteridoideae Briq. and related taxa of Verbenaceae and Lamiaceae using morphological and chemical characters. In: Harley RM, Reynolds T, editors. Advances in Labiatae Sciences. London: Royal Botanic Gardens, Kew; 1992. p. 39-54.

129. Huang MJ. Systematics of Trichostema L. (Lamiaceae) and phylogenetic relationships with its disjunct taxa in Asia. Ph.D. Dissertation. The Ohio State University; 2002.

130. Shi S-H, Du Y-Q, Boufford DE, Gong X, Huang Y-L, He H-H, et al. Phylogenetic position of Schnabelia, a genus endemic to China: Evidence from sequences of cpDNA matK gene and ITS regions. Chin Sci Bull. 2003;48:1576-80.

131. Cantino PD, Wagstaff ST, Olmstead RG. Caryopteris (Lamiaceae) and the conflict between phylogenetic and pragmatic considerations in botanical nomenclature. Syst Bot. 1998;23:369-86.

132. P'ei C, Chen S-L. Verbenaceae. In: Chen SL, Pei J, editors. Flora Reipublicae Popularis Sinicae, Vol. 65(1). Beijing: Science Press; 1982. p. 1-208.
133. Chen S-L, Gilbert MG. Verbenaceae. In: Wu Z-Y, Raven PH, editors. Flora of China, Vol. 17. Beijing: Science Press; St. Louis: Missouri Botanical Garden Press; 1994. pp. 1-49.

134. Paton AJ. A global taxonomic investigation of Scutellaria (Labiatae). Kew Bull. 1990;45:399-450.

135. Paton AJ. The phytogeography of Scutellaria L. Notes Roy Bot Gard Edinburgh. 1990;46:345-9.

136. Li B, Xu W-X, Tu T-Y, Wang Z-S, Olmstead RG, Peng H, et al. Phylogenetic position of Wenchengia (Lamiaceae): a taxonomically enigmatic and critically endangered genus. Taxon. 2012;61:392-401.

137. Ryding O. Amount of calyx fibres in Lamiaceae, relation to calyx structure, phylogeny and ecology. Plant Syst Evol. 2007;268:45-58.

138. Chiang Y-C, Huang B-H, Liao P-C. Diversification, biogeographic pattern, and demographic history of Taiwanese Scutellaria species inferred from nuclear and chloroplast DNA. Plos One. 2012;7:e50844.

139. Zhao F, Liu E-D, Peng H, Xiang C-L. A new species of Scutellaria (Scutellarioideae, Lamiaceae) from Sichuan Province in southwest China. PeerJ. 2017;5:e3624.

140. Safikhani K, Jamzad Z, Saeidi H. Phylogenetic relationships in Iranian Scutellaria (Lamiaceae) based on nuclear ribosomal ITS and chloroplast trnLF DNA data. Plant Syst Evol. 2018;304:1077-89.

141. Scheen A-C, Albert VA. Nomenclatural and taxonomic changes within the Leucas clade (Lamioideae; Lamiaceae). Syst Geogr PI. 2007;77:229-38.

142. Mathiesen C, Scheen A-C, Lindqvist C. Phylogeny and biogeography of the lamioid genus Phlomis (Lamiaceae). Kew Bull. 2011;66:83-99.

143. Bendiksby M, Salmaki Y, Bräuchler C, Ryding O. The generic position of Stachys tibetica Vatke and amalgamation of the genera Eriophyton and Stachyopsis (Lamiaceae subfam. Lamioideae). Plant Syst Evol. 2014;300:961-71.

144. Bean AR. A taxonomic revision of Anisomeles R.Br. (Lamiaceae). Austrobaileya. 2015;9:321-81.

145. Wang Q. A monograph of the genus Microtoena (Lamiaceae). Beijing: Science Press; 2018.

146. Bhatti GR, Ingrouilie M. Systematics of Pogostemon (Labiatae). Bull Nat Hist Mus Lond. (Bot.). 1997;27:77-147.

147. Yao G, Deng Y-F, Ge X-J. A taxonomic revision of Pogostemon (Lamiaceae) from China. Phytotaxa. 2015;200:1-67.

148. Yao G, Drew BT, Yi T-S, Yan H-F, Yuan Y-M, Ge X-J. Phylogenetic relationships, character evolution and biogeographic diversification of Pogostemon s.l. (Lamiaceae). Mol Phylogenet Evol. 2016;98:184-200.

149. Kudô Y. Labiatarum sino-japonicarum prodromus. Mem Fac Taihoku Imp Univ. 1929;2:1-332.

150. Press JR. Taxonomic studies in the Labiatae tribe Pogostemoneae. Bull Nat Hist Mus Lond (Bot). 1982;10:1-89.

151. Keng H. Labiatae. In: CGGJ VS, editor. Flora Malesiana ser. 1, 8(3). Leyden: Noordhoff International Publishing; 1978. p. 301-94.

152. Hasskarl JC. Plantarum genera et species novae aut reformatae Javenses. Flora 25 Beibl. 1842;2(1-2):1-56.

153. Ryding O. Pericarp structure and phylogeny of Lamiaceae subfamily Pogostemonoideae. Nord J Bot. 1994;14:59-63.

154. Ryding O. Pericarp structure and phylogeny of the Lamiaceae-Verbenaceaecomplex. PI Syst Evol. 1995;198:101-41.

155. Xiang C-L, Liu E-D, Peng H. A key to the genus Chelonopsis (Lamiaceae) and two new combinations: C. rosea var. siccanea and C. souliei var. cashmerica comb. nov. Nord J Bot. 2008;26:31-4.

156. Xiang C-L, Dong Z-H, Peng H, Liu Z-W. Trichome micromorphology of the East Asiatic genus Chelonopsis (Lamiaceae) and its systematic implications. Flora. 2010;205:434-41.

157. Xiang C-L, Funamoto T, Evangelista EV, Zhang Q, Peng H. Pollen morphology of the East Asiatic genus Chelonopsis (Lamioideae: Lamiaceae) and allied genera, with reference to taxonomic implications and potential pollination ecology. Plant Biosyst. 2013;147:620-8.

158. Bongcheewin B, Grayer RJ, Porter EA, Kite GC, Simmonds MSJ, Ingrouille MJ, et al. A chemossystematic study of the genus Gomphostemma and related genera (Lamiaceae). Biochem Syst Ecol. 2014;57:305-16.

159. Abu-Asab MS, Cantino PD. Systematic implications of pollen morphology in subfamilies Lamioideae and Pogostemonoideae (Labiatae). Ann Mo Bot Gard. 1994;81:653-86.

160. Ryding O. Pericarp structure in the subtribe Melittidinae (LamiaceaeLamioideae) and its systematic implications. Bot Jahrb Syst. 1994;115:547-55.

161. Ryding O. Pericarp structure in the tribe Prasieae (Lamiaceae-Lamioideae) and its systematic implications. Bot Jahrb Syst. 1994;116:391-9. 
162. Hu G-X, Balangcod TD, Xiang C-L. Trichome micromorphology of the Chinese-Himalayan genus Colquhounia (Lamiaceae), with emphasis on taxonomic implications. Biologia. 2012;67:867-74.

163. Scheen A-C, Lindqvist C, Fossdal CG, Albert VA. Molecular Phylogenetics of tribe Synandreae, a North American lineage of lamioid mints (Lamiaceae). Cladistics. 2008;32:299-314.

164. Roy T, Catlin NS, Garner DMG, Cantino PD, Scheen A-C, Lindqvist C. Evolutionary relationships within the lamioid tribe Synandreae (Lamiaceae) based on multiple low-copy nuclear loci. PeerJ. 2016;4:e2220.

165. WCSP. World Checklist of Selected Plant Families. Facilitated by the Royal Botanic Gardens, Kew. 2020. http://wcsp.science.kew.org/. Accessed 16 Nov 2020.

166. Linnaeus C. Species Plantarum, vol. 2. Stockholmiae: Salvius; 1753.

167. Dumortier BC. Labiatae. In: Dumortier BC, editor. Florula Belgica. Tournay: J. Casterman; 1827. p. 42-9.

168. Bentham G. Labiatae. In: De Candolle A, editor. Prodromus systematis naturalis regni vegetabilis. Vol. 12. Paris: V. Masson; 1848. p. 27-603.

169. Reichenbach L. Labiatae. In: Reichenbach L, editor. Flora Germanica Excursoria. Leipzig: Carolum Cnobloch; 1830-1832. pp. 305-335.

170. Cosson E, German E. Tribu V. Lamioideae. In: Cosson E, German E, editors. Synopsis analytique de la Flore des environs de Paris ou description abregee des familles et des genres. Paris: Fortin, Masson et Cie; 1845. pp. 122-127.

171. Boissier E. Flora Orientalis. Vol. 4(2). Genevae \& Basilea: H. Georg; 1879

172. Bhattacharjee R. Taxonomic studies in Stachys: II. A new infrageneric classification of Stachys L. Notes Roy Bot Gard Edinburgh. 1980;38:65-96

173. Tomas-Bárberán FA, Gil MI, Ferreres F, Tomas-Lorente F. Flavonoid pcoumaroylglucosides and 8-hydroxyflavone allosylglucosides in some labiatae. Phytochemistry. 1992;31:3097-102.

174. Giuliani C, Bini LM. Glandular trichomes as further differential characters between Stachys subgenus Betonica (L.) Bhattacharjee and Stachys subgenus Stachys. Plant Biosyst. 2012;146:1-8.

175. Krestovskaya T. Synopsis of the genus Betonica L. (Lamiaceae). Novosti Sist Vyssh Rast. 2014;45:96-109.

176. Lazkov GA, Sennikov AN. Taxonomic corrections and new records in vascular plants of Kyrgyzstan, 4. Mem Soc. Fauna Flora Fenn. 2015;91:67-83.

177. Ball PW. Stachys L. In: Tutin TG, Heywood VH, Burges NA, Moore DM, Valentine DH, Walters SM, et al., editors. Flora Europaea. Cambridge: Cambridge University Press; 1972. p. 151-7.

178. Visiani R. Labiatae Juss. In: Visiani R, editor. Flora Dalmatica, Vol. 2. Lipsae: Apud Pribdbricum Hofmbistbr; 1847. p. 182-225.

179. Townsend CC. Galeopsis L. In: Tutin TG, Heywood VH, Burges NA, Moore DM, Valentine DH, Walters SM, et al., editors. Flora Europaea, Vol. 3: Diapensiaceae to Myoporaceae. Cambridge: Cambridge University Press; 1972. p. 145-7.

180. Meusel H, Jäger EJ, Rauschert SW, Weiner E. Vergleichende Chorologie der zentraleuropäischen Flora. Text u. Karten. Bd. 2. Jena: VEB Fischer; 1978.

181. Goldblatt P, Johnson DE. Index to plant chromosome numbers 2001-2003. Monogr Syst Bot Missouri Bot Gard. 2006:106:1-242.

182. Tomás-Bárberán FA, Gil MI, Ferreres F, Tomás-Lorente F. Correlations between flavonoid composition and infrageneric taxonomy of some European Galeopsis species. Phytochemistry. 1991;30:3311-4.

183. Müntzing A. Outlines to a genetic monograph of the genus Galeopsis with special reference to the nature and inheritance of partial sterility. Hereditas. 1930;13:185-341.

184. Bendiksby M, Tribsch A, Borgen L, Trávníček P, Brysting A. Allopolyploid origins of the Galeopsis tetraploids - revisiting Müntzing's classical textbook example using molecular tools. New Phytol. 2011;191:1150-67.

185. Lindqvist C, Motley TJ, Jeffrey JJ, Albert VA. Cladogenesis and reticulation in the Hawaiian endemic mints (Lamiaceae). Cladistics. 2003;19:480-95.

186. Salmaki Y, Heubl G, Weigend M. Towards a new classification of tribe Stachydeae (Lamiaceae): naming clades using molecular evidence. Bot J Linn Soc. 2019;190:345-59.

187. Cantino PD, De Queiroz K. International code of phylogenetic nomenclature, version 4c. 2010. https://www.ohio.edu/phylocode/. Accessed 1 May 2020.

188. Abu-Asab MS, Cantino PD. Pollen morphology in subfamily Lamioideae (Labiatae) and its phylogenetic implications. In: Harley R, Reynolds T, editors. Advances in Labiatae science. London: Royal Botanic Gardens, Kew; 1992. p. 361-79.

189. Salmaki Y, Jamazad Z, Zarre S, Bräuchler C. Pollen morphology of Stachys (Lamiaceae) in Iran and its systematic implication. Flora. 2008;203:627-39.
190. Salmaki Y, Zarre S, Jamzad Z. Nutlet micromorphology and its systematic implication in Stachys L. (Lamiaceae) in Iran. Feddes Repert. 2008;119:607-21.

191. Salmaki Y, Zarre S, Jamzad Z, Bräuchler C. Trichome micromorphology of Iranian Stachys (Lamiaceae) with emphasis on its systematic implication. Flora. 2009;204:371-81

192. Salmaki Y, Zarre S, Lindqvist C, Heubl G, Bräuchler C. Comparative leaf anatomy of Stachys (Lamiaceae: Lamioideae) in Iran with a discussion on its subgeneric classification. Plant Syst Evol. 2011;294:109-25.

193. Li HW, Hedge IC. Lamiaceae. In: WU Z-Y, Raven PH, editors. Flora of China, Vol. 17. Beijing: Science Press; St. Louis: Missouri Botanical Garden Press; 1994. pp. 50-299.

194. Ryding O. Pericarp structure and phylogeny of the Phlomis group (Lamiaceae subfam. Lamioideae). Bot Jahrb Syst. 2008;127:299-316.

195. Seyedi Z, Salmaki Y. Trichome morphology and its significance in the systematics of Phlomoides (Lamiaceae; Lamioideae; Phlomideae). Flora. 2015; 213:40-8.

196. Patzak VA. Revision der Gattung Ballota Section Ballota. Ann Naturhist Mus Wien. 1958;62:57-86

197. Sebald O. Die Gattung Otostegia Bentham (Labiatae) in Afrika und auf der arabischen Halbinsel. Stuttgart Beitr Naturk Ser A. 1973;263:1-84.

198. Seybold VS. Revision der Persischen Marrubium-Arten (Labiatae). Stuttgart Beitr Naturk, Ser A. 1978;310:1-31.

199. Scheen A-C, Albert VA. Molecular Phylogenetics of the Leucas Group (Lamioideae; Lamiaceae). Syst Bot. 2009;34:173-81.

200. Kilian N, Hein P, Hubaishan MA. New and noteworthy records for the flora of Yemen, chiefly of Hadhramout and Al-Mahra. Willdenowia. 2002;32:23969.

201. Ryding O. Reconsideration of Wiedemannia and notes on the circumscription of Lamium (Lamiaceae). Bot Jahrb Syst. 2003;124:325-35.

202. Bendiksby M, Brysting AK, Thorbek L, Gussarova G, Ryding O. Molecular phylogeny and taxonomy of the genus Lamium L. (Lamiaceae): Disentangling origins of presumed allotetraploids. Taxon. 2011:60:986-1000.

203. Krawczyk K, Korniak T, Sawicki J. Taxonomic status of Galeobdolon luteum Huds. (Lamiaceae) from classical taxonomy and phylogenetics perspectives. Acta Biol Craco Ser B. 2013;55:18-28.

204. Krawczyk K, Szczecińska M, Sawicki J. Evaluation of 11 single-locus and seven multilocus DNA barcodes in Lamium L. (Lamiaceae). Mol Ecol Resour. 2013;14:272-85.

205. Krestovskaya TV. Menitskia, a new genus of the Labiatae family. Bot Zhurn 2006:91:1892-4.

206. Zhao F, Peng $H$. The complete chloroplast genome of Caryopteris incana (Lamiaceae) and phylogenetic analysis. Mitochondrial DNA B. 2020;5:1399-400.

207. Zhao Y, TO T, Xiang C-L. The complete chloroplast genome of Phlomoides betonicoides (Lamiaceae), a traditional Tibetan medicinal herb. Mitochondrial DNA B. 2020:5:75-6.

208. Xu W-Q, Losh J, Chen C, Li P, Wang R-H, Zhao Y-P, et al. Comparative genomics of figworts (Scrophularia, Scrophulariaceae), with implications for the evolution of Scrophularia and Lamiales. J Syst Evol. 2019;57:55-65.

209. Doyle JJ, Doyle JL. A rapid DNA isolation procedure for small amounts of fresh leaf tissue. Phytochem Bull. 1987;19:11-5

210. Andrews S. Fast QC: A quality control tool for high throughput sequence data. v. 0.10.0. 2010. http://www.bioinformatics.babraham.ac.uk/projects/ fastac.

211. Bankevich A, Nurk S, Antipov D, Gurevich AA, Dvorkin M, Kulikov AS, et al. SPAdes: a new genome assembly algorithm and its applications to single cell sequencing. J Comput Biol. 2012;19:455-77.

212. Kearse M, Moir R, Wilson A, Stones-Havas S, Cheung M, Sturrock S, et al. Geneious Basic: an integrated and extendable desktop software platform for the organization and analysis of sequence data. Bioinformatics. 2012;28: $1647-9$

213. Chen H, Zhang J, Yuan G, Liu C. Complex Interplay among DNA modification, noncoding RNA expression and protein-coding RNA expression in Salvia miltiorrhiza chloroplast genome. Plos One. 2014;9:e99314.

214. Schattner P, Brooks AN, Lowe TM. The tRNAscan-SE, snoscan and snoGPS web servers for the detection of tRNAs and snoRNAs. Nucleic Acids Res. 2005;33:686-9.

215. Lohse M, Drechsel O, Kahlau S, Bock R. Organellar Genome DRAW-a suite of tools for generating physical maps of plastid and mitochondrial genomes and visualizing expression datasets. Nucleic Acids Res. 2013;41:W575-81.

216. Langmead B, Salzberg SL. Fast gapped-read alignment with Bowtie 2. Nat Methods. 2012;9:357-9. 
217. Katoh K, Standley DM. MAFFT multiple sequence alignment software version 7.0: improvements in performance and usability. Mol Biol Evol. 2013; 30:772-80.

218. Müller K, Müller J, Quandt D. PhyDe: Phylogenetic data editor, version 0. 9971. 2010. http://www.phyde.de.

219. Talavera G, Castresana J. Improvement of phylogenies after removing divergent and ambiguously aligned blocks from protein sequence alignments. Syst Biol. 2007;56:564-77.

220. Darriba D, Taboada GL, Doallo R, Posada D. JModelTest 2: more models, new heuristics and parallel computing. Nat Methods. 2012;9:772.

221. Ronquist F, Teslenko M, Van der Mark P, Ayres DL, Darling A, Höhna S, et al. MrBayes 3.2: Efficient Bayesian phylogenetic inference and model choice across a large model space. Syst Biol. 2012;61:539-42.

222. Miller MA, Pfeiffer W, Schwartz T. Creating the CIPRES Science Gateway for inference of large phylogenetic trees. Gateway Computing Environments Workshop (GCE). 2010. p. 1-8.

223. Rambaut A, Suchard MA, Drummond AJ. Tracer v1.6. 2014. http://beast.bio. ed.ac.uk/Tracer.

224. Rambaut A. FigTree, v.1.4.2. 2014. http://tree.bio.ed.ac.uk/software/figtree/. Accessed 16 Dec 2019

225. Stamatakis A. RAxML version 8: A tool for phylogenetic analysis and postanalysis of large phylogenies. Bioinformatics. 2014;30:1312-3.

226. Zhao F, Chen YP, Salmaki Y, Drew BT, Wilson TC, Scheen AC et al. An updated tribal phylogeny of Lamiaceae: evidence from complete plastome sequences. Treebase. http://treebase.org/treebase-web/phylows/study/TB2: S26639? -access-code=bb02a4c5bc226f4604690ea0f21 ccd41\&format=html) Accessed 16 July 2020.

227. Thiers B. Index Herbariorum: a global directory of public herbaria and associated staff. New York Botanical Garden's Virtual Herbarium. 2020. Available at http://sweetgum.nybg.org/ih/. Accessed 16 July 2020.

\section{Publisher's Note}

Springer Nature remains neutral with regard to jurisdictional claims in published maps and institutional affiliations.

Ready to submit your research? Choose BMC and benefit from:

- fast, convenient online submission

- thorough peer review by experienced researchers in your field

- rapid publication on acceptance

- support for research data, including large and complex data types

- gold Open Access which fosters wider collaboration and increased citations

- maximum visibility for your research: over $100 \mathrm{M}$ website views per year

At $\mathrm{BMC}$, research is always in progress.

Learn more biomedcentral.com/submissions 